Revista de Derecho

de la Pontificia Universidad Católica de Valparaíso XXXIII (Valparaíso, Chile, $2^{\text {do }}$ Semestre de 2009)

[pp. 39-102]

\title{
LA EXIGENCIA DE EXTERIORIDAD EN EL CASO FORTUITO: SU CONSTRUCCIÓN A PARTIR DE LA DISTRIBUCIÓN DE LOS RIESGOS DEL CONTRATO
}

["The Requirement of Externality in the Fortuitous Case: its Determination From the Distribution of the Risks of the Contract"]

\author{
María Graciela BrantT \\ Pontificia Universidad Católica de Valparaíso, Chile
}

\section{RESUMEN}

El presente trabajo tiene por objeto reformular la exigencia de exterioridad necesaria para la configuración de un caso fortuito. La intención es proponer una construcción objetiva del requisito, a partir de la función de distribución de riesgos que desempeña todo contrato. De esta forma, será externo o ajeno el hecho que no corresponda a la concreción de un riesgo de incumplimiento de aquellos que por el contrato quedaron comprendidos dentro del ámbito de cargo del deudor y por los cuales éste no puede alegar exoneración.

Palabras Clave: Caso fortuito - Exterioridad - Contrato - riesgos.

\section{ABSTRACT}

This work is aimed at reformulating the requirement of necessary externality in order to determine a fortuitous case. The intention is to propose an objective construction of the requirement, from the function of the distribution of the risks performed in every contract. This way, the event that does not correspond to the determination of risk of infringement in relation to those that, given the nature of the contract, were included within the scope of the debtor's obligation, and for which he cannot claim exoneration, will be considered external or alien.

KEYwORDs: Fortuitous case - Externality - Contract - risks. 


\section{IDEAS PRELIMINARES}

En nuestro derecho, la construcción de la noción de caso fortuito - causa de exoneración de la responsabilidad por el incumplimiento, conforme al artículo 1547 CC.- se ha realizado tradicionalmente a partir de sus tres requisitos: la exterioridad, imprevisibilidad e irresistibilidad del hecho constitutivo del mismo. El objeto de las líneas que siguen es examinar la primera de las exigencias necesarias para que el deudor se vea eximido por la falta de ejecución fiel y oportuna de su obligación: que el hecho que obsta al cumplimiento sea ajeno o extraño a él.

Si bien se trata de un elemento que no está expresamente previsto en la definición del artículo 45 CC., ha sido sostenido constantemente por nuestros autores y admitido también por los tribunales ${ }^{1}$. Es preciso entonces establecer cómo surge en nuestro derecho este requisito del caso fortuito, examinar el sentido atribuido comúnmente al mismo -tanto en nuestro sistema como en el Derecho comparado-, para finalmente determinar el significado que resulta más adecuado para tal exigencia. A mi juicio, es posible reformular la concepción que tradicionalmente ha existido de la exterioridad en nuestro derecho, lo que a su vez permite en cierta forma objetivar el concepto de caso fortuito, demostrando que éste no es simplemente la negación de la culpa, y que no es, consecuentemente, una noción estrictamente subjetiva, como suele ser concebido en nuestro país.

\section{ORIGEN DEL REQUISITO Y SU TRATAMIENTO EN EL DERECHO CHILENO}

\section{La causa extraña del "Code Civil" francés como primer antecedente del requisito. \\ El origen de esta exigencia del caso fortuito puede situarse en el artículo 1147 CC. francés, que impone al deudor, para exonerarse de responsabi- lidad, la necesidad de justificar que la inejecución proviene de una causa}

${ }^{1}$ Sentencias que afirman tal exigencia: Corte de Apelaciones de La Serena, 12 de diciembre de 2006, rol No 971-2006, disponible en www.puntolex.cl; Corte de Apelaciones de Santiago, 23 de enero de 2008, disponible en www.legalpublishing. cl, número identificador 38.265; Corte de Apelaciones de Valparaíso, 7 de enero de 2008, disponible en www.legalpublishing.cl, número identificador 38.171; Corte de Apelaciones de Santiago 27 de septiembre de 2007, rol No 5703-2000, disponible en www.puntolex.cl; Corte Suprema, 24 de agosto de 2006, rol No 1913-2004, disponible en www.puntolex.cl; Corte Suprema, 24 de julio de 2007, disponible en www.legalpublishing.cl, número identificador 36.693; Corte Suprema, 21 de enero de 2008, disponible en www.legalpublishing.cl, número identificador 38.118. 
extraña que no puede imputársele ${ }^{2}$. Y la disposición siguiente del Code, el artículo $1148^{3}$-que sitúa el límite de la indemnización de perjuicios en el caso fortuito- ha sido interpretada, por los primeros comentadores del Code, y luego en general por varios autores franceses posteriores ${ }^{4}$, como complementando la norma precedente, entendiéndose que la causa extraña está constituida precisamente por el caso fortuito.

A partir de la relación establecida entre ambas normas, resulta lógico que en la doctrina francesa se afirme que el caso fortuito constituye un hecho ajeno o extraño al deudor ${ }^{5}$, lo que se traduce finalmente en la exigencia de exterioridad ${ }^{6}$. Ahora bien, no obstante su carácter reiterado, la determinación del contenido preciso de este requisito no ha estado

${ }^{2} \mathrm{El}$ texto de la disposición aludida es el siguiente: "Le débiteur est condamné, s'ily a lieu, au payement de dommages et intérets, soit á raison de l'inexécution de l'obligation, soit á raison du retard dans l'exécution, toutes les fois qu'il ne justifie pas que l'inexécution provient d'une cause étrangére qui ne peut lui etre imputée, encore qu'il n'y ait aucune mauvaise foi de sa part".

${ }^{3}$ Artículo 1148 Code Civil francés: "Il n’y a lieu á aucuns dommages et intérets lorsque, par suite d'une force majeure ou d'un cas fortuit, le débiteur a été empeché de donner ou de faire ce á quoi el était obligé, ou a fait ce qui lui était interdit."

${ }^{4}$ Así se desprende de Rogron, Joseph-André, Les Codes français expliqués (Paris, 1836); y expresamente lo afirma Huc, quien señala que el caso fortuito y la fuerza mayor son las causas extrañas, no personales del deudor que hacen desaparecer su responsabilidad, Huc, Téophile, Commentaire théorique et pratique du code civil (Paris, 1892), VII, p. 201. En igual sentido se pronuncia Esmein, quien afirma que el artículo 1148 del Code llama fuerza mayor o caso fortuito a la causa extraña del artículo 1147. EsMEIN, M. Paul, Le fondement de la responsabilité contractuelle rapproché de la responsabilité délictuelle, en RTDC. 32 (1933), p. 628. También MazEAUd, Henri - Mazeaud, León - Mazeaud, Jean, Lecciones de Derecho civil (Buenos Aires, 1962), II, p. 318.

${ }^{5}$ Así lo expresan Planiol y Ripert, quienes, a propósito de los sucesos que liberan al deudor a pesar del incumplimiento, se pronuncian respecto de la expresión causa extraña, afirmando que alude al carácter externo del obstáculo con relación al deudor. Planiol, Marcel - Ripert, Georges, Traité pratique de droit civil français. Obligations (París, 1931), VI, p. 531. En igual sentido, RiPERT Georges - BOULANGER, Jean, Tratado de Derecho civil según el tratado de Planiol (Buenos Aires, 1956) I, p. 479. Más recientemente, Antonmattei también reconoce -aun cuando la critica- la exterioridad como uno de los elementos -junto a la imprevisibilidad e irresistibilidad-que se impusieron en Francia a lo largo del tiempo en la calificación de la fuerza mayor. Antonmattei, Paul- Henri, Contribution à l'étude de la force majeure (París, 1992), p. 12.

${ }^{6}$ Jurisprudencia en que se recoge el requisito es citada por Antonmattei, Paul Henri, cit. (n. 5), pp. 27 ss. 
exenta de discusión, sino por el contrario, ha dado lugar a gran debate en el derecho civil francés?

Si se considera la importancia del Code Civil para las codificaciones posteriores, no debe extrañar que la exigencia de exterioridad o ajeneidad del caso fortuito haya llegado también a otros ordenamientos influidos por aquel ${ }^{8}$, aunque no siempre de forma expresa, sino fundamentalmente por vía de la interpretación doctrinal ${ }^{9}$. Es así como en España, aunque el artículo 1105 del Código de ese país no lo prevé expresamente, varios autores recogen este requisito ${ }^{10}$, si bien también con interpretaciones disímiles ${ }^{11}$. Algo similar se observa en Chile, como se verá a continuación.

${ }^{7}$ En efecto, Antonmattei se refiere a dicha exigencia como el elemento "plus controversé" de la calificación de la fuerza mayor. Antonmattei, Paul Henri, cit. (n. 5), p. 25. Destacan también el carácter controvertido de esta exigencia, JoRDANO FraGA, Francisco, Las reglas generales de la responsabilidad civil contractual en el sistema del Código Civil español, en ADC. 38 (Madrid, 1985) 2, p. 280; y en Chile Pizarro Wilson, Carlos, La fuerza mayor como defensa del deudor. A propósito de la restricción del suministro de gas a Chile, en GJ. 288 (2004), p. 8, aunque niega su procedencia en nuestro Derecho, opinión que no comparto pues, además del amplio reconocimiento por la doctrina, en nuestro Codice Civile también existe base para aceptarlo.

${ }^{8}$ Cabe tener presente que el Codice Civile italiano de 1865 siguió fielmente las reglas de los artículos 1147 y 1148 del Code, que fueron prácticamente reproducidas en sus artículos 1225 y 1226, que aludían respectivamente, a la causa extraña no imputable al deudor y a la fuerza mayor o caso fortuito, como el fundamento de la exoneración de aquel. Sin embargo, dichas normas no se mantuvieron en el Codice Civile de 1942, el que -recogiendo las ideas de Osti- consagra en el artículo 1218, como límite de la responsabilidad contractual, la imposibilidad de la prestación por causa no imputable al deudor, eliminándose así la expresión "extranea" contenida en el código anterior y que constituía el fundamento literal para la exigencia de exterioridad. Si bien dicha eliminación se ha explicado en razón de la incerteza a que daba lugar [Así lo afirma ANELLI, Franco, Caso fortuito e rischio di impresa nella responsabilitá del vettore (Milano, 1990), p. 37], la citada exigencia se mantiene hoy vigente en la doctrina italiana.

${ }^{9}$ En este sentido, es un hecho claro la influencia ejercida por los autores franceses en la doctrina de los Derechos de tradición continental a partir de la regulación del Code. En el caso de Chile, basta revisar la bibliografía de las obras de nuestros juristas -especialmente los de fines del siglo XIX y primera parte del XX- para constatar el influjo de la doctrina gala. Destacando la influencia aludida se expresa PIZARro Wilson, Carlos, Étude critique sur la responsabilité contractuelle en droit positif chilien (tesis doctoral, Université Pantheon-Assas, París, 2003), p. 14.

${ }^{10}$ Así, entre otros, Borrell y Soler, Antonio María, Cumplimiento, incumplimiento y extinción de las obligaciones contractuales civiles (Barcelona, 1954); LACRUZ Berdejo, José Luis y otros, Elementos de Derecho Civil. Derecho de Obligaciones. Parte General. Teoría General del Contrato (Barcelona, 1994) II, 1, pp. 195 ss.

${ }^{11}$ Como veremos luego, en la doctrina española están presentes las dos grandes formas de concebir la exterioridad: subjetiva y objetiva, adquiriendo esta última gran relevancia en el último tiempo. 


\section{Fundamento y concepción de la exterioridad en la doctrina nacional.}

El examen de los trabajos de los autores nacionales, desde la entrada en vigencia del Código Civil hasta la actualidad, muestra la consideración de la exterioridad como un requisito necesario para la configuración del caso fortuito. Son frecuentes las afirmaciones que aluden a esta exigencia, requiriéndose que "el hecho sea por completo ajeno al deudor"12; o bien, que se trate de una "causa extraña al deudor"13. Igualmente, se recoge el requisito de forma menos explícita cuando se afirma que es necesario que "el hecho se produzca independientemente de la voluntad del deudor" ${ }^{\prime 14}$.

Esta última forma de expresarlo se explica por el modo en que comúnmente ha sido concebida la exterioridad por nuestra doctrina: en vinculación directa con una apreciación de la intención del deudor, haciendo derivar la ajeneidad de la falta de culpa de éste en relación con el evento que obsta al cumplimiento. En efecto, es habitual que la exigencia de que el hecho sea ajeno o extraño al deudor se explique afirmando como necesario que aquel sea independiente de su voluntad ${ }^{15}$, de modo que se termina

${ }^{12}$ Meza Barros, Ramón, Manual de Derecho civil (9a edición, Santiago, 1997), p. 237.

${ }^{13}$ Así expresan el requisito: Fueyo Laneri, Fernando, Derecho Civil, IV: De las obligaciones (Santiago, 1958), I, p. 263; Vial DEL Río, Víctor Manuel, Manual del Derecho de las obligaciones en el Código Civil Chileno (Santiago, 2003), p. 225. Resulta necesario destacar el empleo de esta expresión para aludir a la exigencia en cuestión, pues coincide con la fórmula utilizada por el artículo 1147 del Código Civil francés, y muestra por lo tanto, la influencia antes mencionada de este último y su doctrina en nuestros autores.

${ }^{14}$ Vodanovic, Antonio, Curso de Derecho civil basado en las explicaciones de don Arturo Alessandri y Manuel Somarriva, III: De las Obligaciones (Santiago, 1941), p. 184. En forma similar, Claro Solar, quien afirma que se requiere que "el hecho provenga de una causa enteramente ajena a la voluntad del deudor". Claro SOLAR, Luis, Explicaciones de Derecho civil chileno y comparado (Santiago, 1978, reimpresión de la segunda edición), X y XII, p. 537. Barros Errázuriz se refiere al requisito afirmando que es necesario que "el acontecimiento provenga de una causa ajena a la voluntad del deudor”. Barros Errázuriz, Alfredo, Curso de Derecho civil, segundo año: De las obligaciones en general (Santiago, 1932), p. 86. En una línea análoga, Rodríguez Grez, quien se refiere al caso fortuito como una causa extraña, indicando como uno de los requisitos del mismo, que se trate de un hecho independiente de la voluntad de las partes, independiente de su intención y conducta. Rodríguez Grez, Pablo, Responsabilidad contractual (Santiago, 2003), p. 181.

${ }^{15}$ Así, por ejemplo, Alessandri, Arturo - Somarriva, Manuel - Vodanovic, Antonio, Tratado de las Obligaciones (2a edición, Santiago, 2004), p. 279, quienes afirman que "el hecho debe ser generado por una causa extraña a la voluntad del deudor", y agregan luego que "el hecho debe ser generado por una causa enteramente ajena a la voluntad del deudor". También en alguna medida Claro Solar, pues si bien se aprecia en él una tendencia a concebir la exigencia en términos más bien objetivos, 
dando una connotación subjetiva a dicho requisito. Esto es más claro aún cuando tal necesidad de independencia del hecho respecto de la voluntad del deudor se justifica afirmándose que si aquel se produce por culpa de éste, no habrá exención de responsabilidad. Así lo expresan Alessandri y Somarriva, aseverando que es por ello que "el legislador establece que el deudor no queda eximido de responsabilidad cuando el caso fortuito se produce durante su culpa o mora"16.

Esto último se relaciona con el fundamento positivo que tradicionalmente se ha dado a la exigencia de la exterioridad en nuestro derecho. La doctrina generalmente ha fundado este requisito en el artículo 1547 inciso $2^{\circ} \mathrm{CC}$., cuando establece como necesario, para la exención del deudor, que el caso fortuito no haya sobrevenido por su culpa ${ }^{17}$. Dicha disposición ha contribuido a que en la mayoría de los autores nacionales se advierta esta visión subjetiva de la exterioridad, identificada con la ausencia de culpa del deudor respecto del hecho que le impide cumplir su obligación. Así, la exterioridad termina traduciéndose en la necesidad de que el suceso sea totalmente ajeno a la conducta culpable del deudor ${ }^{18}$.

calificando en varios pasajes de su obra al caso fortuito simplemente como "causa extraña”, cuando enumera los requisitos necesarios para que un hecho constituya caso fortuito, la primera exigencia que afirma es que aquel "provenga de una causa enteramente ajena de la voluntad del deudor". Claro Solar, Luis, cit. (n. 14), pp. 524 y 537. En la jurisprudencia: sentencia de la Corte de Apelaciones de Santiago de 23 de enero de 2008, cit. (n. 1); Sentencia Corte Suprema, de 21 de enero de 2008, cit. (n. 1).

${ }^{16}$ Vodanovic, Antonio, Curso de Derecho civil, cit. (n. 14), p. 184. En similar sentido se pronuncia Barros Errázuriz, Alfredo, cit. (n. 14), p. 86. Asimismo, Meza Barros, quien agrega que cuando el caso fortuito sobreviene por culpa o durante la mora del deudor, éste no es totalmente extraño a la producción del hecho que los constituye. Meza Barros, Ramón, cit. (n. 12), p. 237.

${ }^{17}$ Señalan expresamente dicha norma como el fundamento de la exigencia: Alessandri, Arturo, Somarriva, Manuel, Vodanovic, Antonio, cit. (n. 15), p. 279. También lo hace Abeliuk Manasevich, René, Las Obligaciones² (Santiago, 1983), p. 532, aunque cabe tener presente que este último autor critica la expresión del legislador en la citada disposición cuando se refiere a la posibilidad de que el caso fortuito haya sobrevenido por culpa del deudor, en tanto a su juicio la existencia de culpa impide que haya caso fortuito. Eso lo lleva a explicar la exterioridad en términos más cercanos al plano de la causalidad, como luego diré. Incluso, la misma fundamentación le ha dado la jurisprudencia. Así, en una sentencia de la Corte de Apelaciones de Santiago se afirma que para constituir caso fortuito, el hecho debe ser ajeno a la voluntad del deudor, lo que se desprende del artículo 1547, que lo establece como responsable del caso sobrevenido por culpa. Sentencia disponible en www.legalpublishing.cl, número identificador 20.626.

${ }^{18}$ En este sentido, cabe citar la opinión de Coustasse, Alberto - ITURRA, Fernando, El caso fortuito ante el Derecho civil (Santiago, 1958), p. 109. Si bien estos 
Ahora bien, cabe destacar la existencia en la doctrina nacional de algunas opiniones que, aunque aisladas, dan cuenta de una forma de concebir la exterioridad que difiere de la opinión mayoritaria recién descrita. Se trata de autores que explican esta exigencia sin recurrir a la noción de culpa, llevando su fundamento y contenido al plano de la causalidad. De acuerdo a este planteamiento, la exterioridad consistiría en la ausencia de vínculo causal entre la conducta del deudor y el hecho que ocasiona el incumplimiento contractual. Esta forma de concebir la exterioridad se advierte incluso, aunque no siempre de manera clara, en las opiniones de algunos de nuestros juristas más tradicionales. Es el caso, por ejemplo, de Claro Solar, que si bien formula el requisito en términos que se acercan a la concepción mayoritaria al exigir que el hecho "provenga de una causa enteramente ajena de la voluntad del deudor" 19 , lo explica señalando que es necesario que "el deudor no haya contribuido en forma alguna a su producción" ${ }^{20}$, con lo que parece concebir el requisito exclusivamente a partir de la existencia o no de incidencia causal de la conducta del deudor en el evento. Algo similar ocurre con Fueyo, quien explicando la "causa extraña" -como denomina al primer elemento del caso fortuito- afirma que "para que exista caso fortuito el deudor no debe ser el causante de la situación de incumplimiento", agregando más adelante que "el deudor es, entonces, persona ajena al resultado" ${ }^{21}$. Sus expresiones permiten apreciar un enfoque de la ajeneidad distinto del tradicional, especialmente teniendo en cuenta que luego afirma que el caso fortuito "no admite la intervención directa y causal del propio deudor"22, apareciendo una vez más la idea de causalidad en relación con la exigencia en estudio ${ }^{23}$. Por último, en la

autores no incluyen de manera expresa la exterioridad del hecho como requisito del caso fortuito, sino que mencionan como primera exigencia -a la que se agregan la imprevisibilidad e irresistibilidad del artículo 45- la inimputabilidad del suceso al deudor, la forma en que ésta es explicada se acerca al contenido que tradicionalmente nuestra doctrina le ha dado a la extraneidad del hecho, en tanto afirman la necesidad de que éste no derive en modo alguno de la conducta culpable del deudor, respecto de la cual el hecho debe ser ajeno.

${ }^{19}$ Claro Solar, Luis, cit. (n. 14), p. 537.

${ }^{20}$ Ibíd.

${ }^{21}$ Fueyo Laneri, Fernando, Derecho civil, cit. (n. 13), p. 263.

${ }^{22}$ Ibíd, p. 264.

${ }^{23}$ Hay que señalar, sin embargo, que a pesar de esta perspectiva causal que parece primar en el autor citado en relación con la ajenidad, no están del todo ausentes en la explicación de la misma, alusiones a la culpa, con lo que resulta difícil definir de manera precisa en cuál de las dos tendencias descritas se ubica su visión del requisito. Algo similar ocurre con Abeliuk, quien primero se refiere a la exterioridad afirmando que el hecho debe ser extraño a la voluntad de las partes, y señala que el fundamento de la exigencia estaría en la regla ya citada del inciso segundo del artículo 1547, 
doctrina más reciente, Baraona se pronuncia expresamente en el sentido de que la extraneidad -que a su juicio constituye el elemento central del fortuito- debe ser entendida "en términos de quiebre causal" ${ }^{24}$, optando así por una perspectiva distante de la idea de culpa.

Estos son los dos significados que en nuestro derecho se ha atribuido al requisito de la ajeneidad en el caso fortuito. Como puede apreciarse, sin perjuicio de aquellos pocos casos en que ella es -o parece ser- concebida en términos estrictamente causales, lo cierto es que predomina una visión subjetiva de la misma, en tanto la generalidad de la doctrina hace depender su concurrencia de una valoración de la conducta desplegada por el deudor, equiparando la exterioridad a la falta de culpabilidad de éste respecto de la producción del hecho que afecta el cumplimiento.

En mi opinión, sin embargo, ninguna de estas dos formas de entender la ajeneidad resulta satisfactoria. Ello porque no asignan al requisito un contenido propio pues, para explicarlo, recurren al presupuesto de la responsabilidad contractual que el caso fortuito afectaría, y que justificaría su función de causa de exoneración: la exclusión de la culpa o la ausencia de nexo causal entre el deudor y el hecho que ocasiona el incumplimiento ${ }^{25}$.

ubicándose así, en principio, en la perspectiva mayoritaria; para luego afirmar que lo que en realidad el precepto en cuestión quiere decir es que "el hecho que se invoca como fuerza mayor no debe haber sido provocado por el deudor", con lo que parece acercarse, aunque no expresamente, a la idea de causalidad. Abeliuk Manasevich, René, cit. (n. 17), p. 532. Sin embargo, y como se verá más adelante, prevalece en el autor una visión más bien subjetiva del requisito, en tanto la exoneración por caso fortuito la funda finalmente en la eliminación de la culpa.

${ }^{24}$ BARAONA GONZÁLEZ, Jorge, Responsabilidad contractual y factores de imputación de daños: apuntes para una relectura en clave objetiva, en RChD. 24 (1997) 1, p. 175. Cabe tener en cuenta que la concepción del autor acerca de la exterioridad se inserta en su intención de promover una objetivación de la responsabilidad contractual en nuestro Derecho, con lo que resulta lógico que opte por una noción de aquella completamente desvinculada de la idea de culpa. En términos cercanos se expresa Pizarro, quien si bien no considera la exterioridad como requisito del caso fortuito, postula que éste sólo tiene cabida en las obligaciones de resultado, cuyo régimen de responsabilidad sería objetivo, y que la exoneración se fundaría en que el caso fortuito interrumpiría el vínculo causal entre el hecho o la omisión del demandado y el daño causado. Pizarro Wilson, Carlos, La fuerza mayor, cit. (n. 7), p. 13. De esta forma, el autor centra el juicio de responsabilidad exclusivamente en la existencia de una relación de causalidad material entre deudor e incumplimiento. En la jurisprudencia, un fallo que parece acoger, aunque no la desarrolla, esta idea de exterioridad vinculada con la causalidad es el de la Corte de Apelaciones de Santiago, de 27 de septiembre de 2007, cit. (n. 1), en que se afirma: "Que el hecho deba ser generado por una causa extraña a la voluntad del deudor significa que éste no ha debido contribuir de ninguna manera a causarlo".

${ }^{25}$ Esto es más claro cuando se sostiene, como es el caso de Baraona, la existencia 
El problema es que de esa forma, la exterioridad deja de ser propiamente un requisito autónomo del caso fortuito. Conforme a la tesis mayoritaria, termina en definitiva siendo la consecuencia de la verificación de los restantes elementos de la noción: imprevisibilidad e irresistibilidad, que a su vez equivalen a la ausencia de culpa del deudor. Y en el caso de la segunda postura doctrinal, la ajeneidad resulta simplemente de constatar que el deudor no puede considerarse como causa material y directa del incumplimiento. Con ello, la exterioridad pierde relevancia en sí misma. Por esta razón, creo necesario reformular el requisito, a fin de dotarlo de un contenido propio, de modo que -conjuntamente con la imprevisibilidad e irresistibilidad-contribuya efectivamente a la configuración del caso fortuito como regla de exoneración, y al mismo tiempo, de atribución de responsabilidad por el incumplimiento contractual.

Para cumplir este objetivo, es de gran utilidad considerar el tratamiento que este requisito ha recibido en el derecho y la doctrina comparada, lo que puede dar luces para una adecuada interpretación de la exterioridad en nuestro sistema.

\section{LA EXTERIORIDAD EN EL DERECHO Y DOCTRINA COMPARADOS}

El examen de la regulación y el tratamiento doctrinal dado a la materia en otros ordenamientos, muestra diversas posibilidades de comprender y explicar la exigencia de exterioridad del caso fortuito, o bien, de la causa de exoneración, en aquellas regulaciones que no dan tal denominación al límite de la responsabilidad del deudor ${ }^{26}$.

En particular, en los derechos pertenecientes a la tradición continental, se advierte una doble interpretación del requisito: por un lado, una de corte

de un régimen objetivo de responsabilidad, resultante del solo incumplimiento y sin que la culpa desempeñe función alguna. Con dicha interpretación, es lógico que en la explicación de la exterioridad se ponga énfasis exclusivamente en la ausencia de nexo de causalidad que el caso fortuito implicaría, como lo hace el autor.

${ }^{26}$ Es el caso de los cuerpos normativos que conforman el Derecho uniforme -CV., PECL., Principios de Unidroit, entre otros-, que si bien prevén una causa de exoneración, que desempeña la función de límite de la responsabilidad del deudor, no le dan la denominación de caso fortuito -salvo los Principios de Unidroit, que la llama fuerza mayor- en tanto la eximente responde a los principios particulares que los inspiran. Sin perjuicio de ello, la idea de extraneidad de la causa de exención está presente también en dichos sistemas, con un contenido que en alguna medida se acerca a lo que ha sido una de las concepciones de la misma en los ordenamientos continentales, y que puede servir sin duda de modelo a la hora de construir el requisito en nuestro Derecho. 
subjetivo -similar a la sostenida mayoritariamente en Chile-; y por otro, una de carácter objetivo ${ }^{27}$, principalmente inspirada en la idea de fundar objetivamente la responsabilidad contractual.

Por su parte, es importante también considerar el tratamiento de la exterioridad en la regulación de la causa de exoneración en los cuerpos normativos que integran el denominado derecho uniforme de los contratos. En ellos se asigna a la misma un contenido objetivo que resulta de interés, en tanto se recoge la función de distribución de riesgos que desempeñan los contratos desde una perspectiva práctica y económica, lo que corresponde a una visión realista del contrato que es necesario tener en cuenta al interpretar las normas del Código Civil.

Ahora bien, hay que adelantar que lo que indudablemente caracteriza a la exterioridad es que constituye una noción o concepto de carácter referencial, es decir, su definición supone necesariamente la determinación de un elemento respecto del cual se realiza la calificación del hecho como externo o ajeno ${ }^{28}$. Según cuál sea ese elemento, surgen diversas formas de entenderla.

\section{Derecho continental: concepción subjetiva y objetiva de la exteriori- dad.}

a) Exterioridad en sentido subjetivo. Coherentemente con la influencia de la tradición romana, y por consiguiente, de una perspectiva en principio estrictamente subjetiva del sistema de responsabilidad contractual, construida a partir de la noción de culpa y del caso fortuito entendido como negación de la misma, resulta lógico que la exterioridad se conciba en estos sistemas precisamente en relación con la conducta del deudor, dando lugar a una concepción subjetiva. Conforme a ésta, la exterioridad del hecho que afecta el cumplimiento queda determinada por la ajeneidad

\footnotetext{
${ }^{27}$ Aluden expresamente a estos dos sentidos en que se ha concebido la exterioridad como requisito del caso fortuito: Antonmattei, Pierre Henri, cit. (n. 5), p. 25, quien distingue entre exterioridad material y sicológica; y por su parte, COMPORTI, Mario, Causa estranea, caso fortuito, responsabilità oggetiva, en FI. 2 (1985) 1, n. 2, quien menciona la existencia de dos sentidos dados a la exterioridad, que califica como riguroso y menos riguroso, los que en definitiva coinciden con la visión objetiva y subjetiva aquí aludida.

${ }^{28}$ En este sentido se pronuncia Antonmattei quien afirma: "l'extériorité n’a sens que par rapport à un objet de référence” Antonmattei, Pierre Henri, cit. (n. 5), p. 25. También destaca esta característica de la noción en estudio Carrasco, quien expresa: "Decir "interno" o "externo" no es decir nada si no se nos da la situación a partir de la cual un hecho es externo o interno". CARRASCo Perera, Ángel Francisco, Artículo 1105 Código Civil, en Albaladejo, Manuel (director), Comentarios al Código Civily Compilaciones Forales (Madrid, 1989), p. 38.
} 
respecto de la voluntad del deudor, a su intención, lo que ha llevado a calificarla como una acepción sicológica ${ }^{29}$. En definitiva, según esta tesis, la función de la exterioridad es demostrar la inimputabilidad del evento al deudor $^{30}$, lo que se traduce en definitiva en excluir la existencia de culpa en la aparición del hecho ${ }^{31}$, en descartar un comportamiento reprochable de su parte que haya dado lugar al impedimento ${ }^{32}$.

Esta es la forma en que comúnmente se explica la exterioridad como requisito o elemento del caso fortuito: independencia de la voluntad o falta de imputabilidad subjetiva del hecho respecto del deudor. Se trata, como he dicho, de una tesis de gran influencia entre los partidarios de un régimen subjetivo de responsabilidad contractual ${ }^{33}$. Así por ejemplo, en Francia, en relación con el sentido de la norma del artículo 1147 del

${ }^{29}$ Así la califica Antonmattei, siguiendo una expresión utilizada en Francia por Radouant, a quien el autor atribuye la proposición de interpretar la causa extraña del artículo 1147 del Code en el sentido expresado, dando lugar con ello a esta concepción sicológica de la exterioridad, que según el mismo no es en realidad una exigencia autónoma del caso fortuito, en tanto estima que es absorbida por la inevitabilidad exigida al evento. Ésta, a su juicio, es suficiente para excluir la posibilidad de reprender al sujeto por la aparición de la fuerza mayor. Con esta crítica, en definitiva el autor asume de cierta forma la visión subjetiva de la noción, ya que implícitamente la refiere a la reprochabilidad del suceso al deudor. Antonmattei, Pierre Henri, cit. (n. 5), pp. 39 ss.

${ }^{30}$ Antonmattei, Pierre Henri, cit. (n. 5), p. 40. Respecto de esta identificación entre exterioridad e inimputabilidad se pronuncia en Italia Comporti. El autor, al referirse a la interpretación del requisito de extraneidad del artículo 1225 del código de 1865 , alude a la doble interpretación a que dio lugar dicha exigencia, siendo una de ellas de carácter subjetivo, en tanto la exterioridad era medida en relación con la voluntad del deudor. Tal interpretación a su juicio no era convincente teniendo en cuenta que la misma norma exigía además la inimputabilidad del deudor. COMPORTI, Mario, cit. (n. 27), pp. 1.648-1.649.

${ }^{31}$ Esto es en definitiva consecuencia de que, a su vez, la imputabilidad tradicionalmente ha sido entendida subjetivamente, es decir, en relación directa con la posibilidad de atribución de culpa al sujeto respecto del cual se realiza el juicio de imputabilidad. Esto quizá tiene su origen en que comúnmente, al tratarse los requisitos de la responsabilidad, se ubica entre ellos el de la imputabilidad del incumplimiento al deudor, la que se explica, como es lógico en un sistema subjetivo de responsabilidad, recurriendo a la culpabilidad como factor de atribución. De esta forma, no es difícil que entendiendo la exterioridad como negación de imputabilidad del hecho al sujeto, se llegue a identificar la misma con la falta de culpa.

${ }^{32}$ Antonmattei, Pierre Henri, cit. (n. 5), pp. 40-41.

${ }^{33}$ En este sentido, Del Olmo, refiriéndose al caso francés, y al italiano bajo el Código de 1865, afirma que la interpretación de la causa extraña como equivalente a causa no imputable fue empleada por los partidarios de la equiparación casus y non culpa. Del Olmo Guarido, Natalia, El caso fortuito: su incidencia en la ejecución de las obligaciones. Doctrina y jurisprudencia (Navarra, 2004), p. 37. 
Code, se ha afirmado que la exterioridad implica excluir la imputabilidad ${ }^{34}$. En Italia, bajo la vigencia del Códice Civile de 1865, Chironi afirmaba que la exigencia de que el hecho fuera extraño al deudor no quería decir nada distinto a hecho no imputable ${ }^{35}$. Y luego, bajo la vigencia del código de 1942, también hay quien defiende una acepción subjetiva de la extraneidad, considerándola como requisito de la causa no imputable del artículo $1218^{36}$. En España, por su parte, ocurre algo similar a lo que se aprecia en Chile: la doctrina tradicional postula el sentido subjetivo de la exterioridad, afirmando como requisito del caso fortuito la independencia respecto de la voluntad del deudor, entendida como inimputabilidad del suceso constitutivo del mismo ${ }^{37}$.

Ahora bien, frente a esta forma de entender la exterioridad se encuentra otra visión de la misma, que deja de apuntar a la voluntad o aspecto sicológico del deudor para calificar el evento como ajeno, y por el contrario, intenta construir el requisito empleando como punto de referencia un criterio objetivo, alejado de una apreciación de la conducta del sujeto.

b) La exterioridad en un sentido objetivo: la noción de Exner y la responsabilidad por riesgo de empresa. La doctrina

\footnotetext{
${ }^{34}$ Así lo afirma Wigny, Pierre, Responsabilité contractuelle et force majeure, en RTDC. (1935), p. 70.

${ }^{35}$ Chironi, G. P., Culpa en el Derecho civil moderno. La culpa contractual (Madrid, 1928), p. 761.

${ }^{36}$ Así lo afirma Cottino, quien hace equivalentes las nociones de caso fortuito, fuerza mayor y causa no imputable, al expresar que "tali termini avrebbero sempre in ogni caso valore de sinonimi", y afirma luego que "la causa estranea si reconduce così alla causa no imputabile (estranea in senso soggetivo: cioè all'atto cosciente $\mathrm{e}$ voluntario del debitore)", dando así expresamente un sentido subjetivo a la extraneidad. Cottino, Gastone, Voz caso fortuito e forza Maggiore, en Enciclopedia del Diritto (Milano, 1960), VI, pp. 381-382. El autor se aparta así de quienes -entre ellos, VISINTINI, Giovanna, Responsabilidad contractual y extracontractual: estudios sobre el incumplimiento de obligaciones y los hechos ilícitos en el Derecho y la jurisprudencia civil (trad. española, Lima 2002), pp. 67 y 150- considerando equivalentes las nociones de causa no imputable y caso fortuito, asignan a la extraneidad un sentido objetivo.

${ }^{37}$ En este sentido se pronuncia Manresa, quien agrega que para que se verifique esa inimputabilidad es necesario encontrarse en alguno de los dos supuestos establecidos en el artículo 1105 del Código Civil español: hecho imprevisto o bien previsto pero inevitable. Manresa, José María, Comentarios al Código Civil. Artículo 1105 (6 ${ }^{a}$ edición, Madrid, 1967) VIII, I, p. 248. De esta forma, se aprecia en su opinión un razonamiento similar al seguido por la mayoría de nuestros autores, que -como señalé anteriormente- también hacen depender la exterioridad de la imprevisibilidad e irresistibilidad del evento.

Por su parte, Lacruz también adopta esta concepción de la exterioridad cuando afirma que "el caso es un suceso externo y ajeno al deudor, independiente de su voluntad”. LaCruz Berdejo, José Luis y otros, cit. (n. 10), p. 174.
} 
comparada coincide en que esta forma de concebir la exterioridad tiene sus orígenes en la obra de Exner $^{38}$, quien -tratándose del contrato de transporte, y particularmente, de la responsabilidad del porteador por los bienes transportados ${ }^{39}$ - postula una noción de fuerza mayor caracterizada porque la exterioridad del hecho no se construye en relación con la voluntad o conducta culpable del deudor, sino respecto de los bienes y personas que integran su industria.

En concreto, el autor propone una noción de fuerza mayor determinada por dos criterios: uno cualitativo y otro cuantitativo ${ }^{40}$. El cualitativo-que debe apreciarse en primer lugar- está constituido precisamente por la exterioridad, entendida como origen externo del daño respecto del círculo industrial de la empresa ${ }^{41}$, dentro del cual el autor afirma la existencia de una responsabilidad absoluta, sin posibilidad de exoneración para el empresario, por lo que un evento originado dentro de dicho círculo nunca puede constituir fuerza mayor ${ }^{42}$. De esta forma, la exterioridad se concibe en un sentido material ${ }^{43}$, y se construye a partir de un ámbito objetivo: el círculo industrial del deudor, con independencia de su voluntad ${ }^{44}$. Según

${ }^{38}$ Así lo afirman: Antonmattei, Paul Henri, cit. (n. 5), p. 26; Del Olmo GuaRIDO, Natalia, cit. (n. 33), p. 44; TrimarCHI, Pietro, Il caso fortuito quale limite della responsabilità peri l danno da cose, en RTDPC. (1959) 2, p. 838; CarrasCo Perera, Ángel Francisco, Artículo 1105, cit. (n. 28), p. 38; Wigny, Pierre, cit. (n. 34), p. 68 .

${ }^{39} \mathrm{Si}$ bien el autor realiza su estudio: De la fuerza mayor en el Derecho mercantil romano y en el actual (Trad. español, Madrid, 1905), fundamentalmente sobre la base del transporte marítimo, su intención es extender los principios propuestos a todas las figuras que coinciden con los supuestos de responsabilidad ex recepto del Derecho romano, en que el autor encuentra los antecedentes de sus postulados, y para las cuales estima procedente un régimen de responsabilidad objetiva. Así pues, por ejemplo, sus proposiciones valen también para el hostelero, y además, teniendo en cuenta la importancia adquirida por el transporte terrestre en su época, se extienden también a dicho contrato.

${ }^{40}$ EXNER, Adolf, La fuerza mayor en el Derecho mercantil romano y en el actual (trad. española, Madrid, 1905), p. 133.

${ }^{41}$ Ibíd., p. 134.

${ }^{42}$ Ibid, pp. 16, 134, 140 y 141. El autor califica la regla de exterioridad propuesta como una norma de seguro, en tanto el porteador actuaría en su círculo industrial como una especie de asegurador de los objetos transportados.

${ }^{43}$ Como señalé anteriormente, Antonmattei emplea la expresión "materielle" para referirse a esta concepción en que la exterioridad es determinada no respecto de la voluntad del deudor, sino en relación a una cosa, actividad o persona, visión que según afirma, se atribuye clásicamente a Exner. Antonmattei, Paul Henri, cit. (n. 5), pp. 25-26.

${ }^{44}$ Dicho círculo el autor lo estima conformado por los espacios y objetos empleados en las actividades de la empresa -incluyendo a eventuales subempresas-así como 
el autor, "hay que considerar como una unidad al conjunto de seres y fuerzas que cooperan en una empresa industrial tal como se presentan de hecho en el tráfico ante el público" ${ }^{45}$, y agrega que desde el punto de vista jurídico ellos son "elementos integrantes del sujeto eventualmente obligado a indemnizar" ${ }^{46}$, explicando así que los daños que se producen al interior de la empresa sean de cargo de empresario ${ }^{47}$.

Se advierte entonces que la noción de exterioridad que Exner propone es, como él mismo la califica, bastante rigurosa ${ }^{48}$, en el sentido que el ámbito que conforma el círculo industrial se delimita muy rígidamente, en relación estricta con las cosas o personas involucradas en la organización del empresario. Se trata en definitiva, de una noción que puede calificarse como espacial ${ }^{49}$, ya que el círculo industrial está delimitado por el área ocupado por la empresa: todo lo que se origine dentro de ese espacio físico queda excluido de la noción de fuerza mayor. Ésta empieza donde termina el mismo, en la medida, por supuesto, que concurra también el aspecto cuantitativo requerido ${ }^{50}$.

De acuerdo a lo expresado, y frente a la perspectiva sicológica de la exterioridad antes descrita, la propuesta de Exner constituye indudablemente una visión más objetiva de la misma, pues se aleja, para definirla, de la idea

por el personal que se encuentre en funciones, pues en esas circunstancias constituye un instrumento de la misma. A partir de su noción de circulo industrial, el autor afirma, por ejemplo, que la huelga del personal de la empresa no constituye fuerza mayor, como tampoco un incendio generado en una hospedería, a diferencia de lo que ocurriría si la paralización del trabajo es consecuencia de una orden de movilización que llame a las armas a los trabajadores, o si el incendio procede de una casa vecina. EXNER, Adolf, cit. (n. 40), pp. 145-146.

${ }^{45}$ Ibíd, p. 148

${ }^{46}$ Ibíd.

${ }^{47} \mathrm{El}$ autor afirma que su propuesta se basa en una consideración jurídico-práctica, vinculada con las razones de orden probatorio que constituyen el fundamento último de su tesis: la desigualdad en que se encuentran las partes respecto de la prueba, en el sentido que el empresario maneja el interior de su empresa, pudiendo influir -incluso fraudulentamente- en las pruebas que se presenten para descartar su responsabilidad, a diferencia de lo que ocurre con el acreedor afectado, que ningún acceso tiene a dicha organización, de modo tal que, según el autor, el concepto de fuerza mayor que propone viene a constituir un medio de protección para éste último.

${ }^{48}$ Exner, Adolf, cit. (n. 40), p. 142. Por su parte Del Olmo Guarido, Natalia, cit. (n. 33), p. 44, la califica como "absoluta".

${ }^{49}$ Así lo califica Trimarchi, Pietro, Il caso fortuito, cit. (n. 38), p. 840.

${ }^{50}$ El elemento cuantitativo está constituido por la magnitud que debe tener el evento, que según el autor, por su clase e importancia debe exceder el curso normal de la vida. ExNER, Adolf, cit. (n. 40), p. 185. 
de la voluntad o culpa del deudor ${ }^{51}$. Sin embargo, la forma tan estricta en que construye el círculo industrial, delimitándolo desde una perspectiva más bien geográfica o física, impide que se arribe a un concepto de exterioridad vinculado con la idea de riesgo de empresa ${ }^{52}$. Ésta es una noción más lata, que comprende todos los peligros que involucra la actividad de preparación y ejecución de la prestación por parte del deudor, sin que puedan reducirse exclusivamente a los riesgos surgidos en el espacio físico en que se ubica la empresa, que es lo que en definitiva propone Exner. No obstante ello, el paso que da hacia la objetivación de la exterioridad constituye indudablemente el antecedente de las doctrinas posteriores que intentan construir un sistema de responsabilidad contractual objetiva, utilizando para ello la noción más amplia de riesgo de empresa ${ }^{53}$, lo que implicará, como es lógico, concebir la exterioridad del caso fortuito a partir de la misma idea.

En efecto, la noción de riesgo de empresa, si bien surge en el ámbito de la responsabilidad extracontractual -con la intención de dejar atrás la culpa como fundamento de la misma, permitiendo la atribución de responsabilidad por la sola realización, en provecho propio, de actividades peligrosas para terceros- es luego recogida en sede contractual para

${ }^{51}$ Aun cuando en su concepto de fuerza mayor no logra, a pesar de su intención de hacerlo, desvincularse totalmente de dicha noción. Así lo afirma Carrasco Perera, quien refiriéndose a la caracterización que Exner hace de la exterioridad, afirma que su teoría se basa en "sospechas típicas de culpa", Carrasco Perera, Ángel Francisco, Artículo 1105, cit. (n. 28), p. 38. En sentido similar se pronuncian TrimarCHI, Pietro, Il caso fortuito, cit. (n. 38), p. 840 y WigNY, Pierre, cit. (n. 34), p. 69, quien llega a afirmar que lo que Exner hace es construir presunciones de culpa que rigen ante la falta de prueba de la exterioridad del hecho a la empresa del deudor. Estas afirmaciones se basan fundamentalmente en que, no obstante señalar reiteradamente que su intención es eliminar la cuestión de la culpa, el autor igualmente termina estableciendo una relación entre la noción de fuerza mayor que propone y la culpa del deudor. Así, tratándose del círculo industrial, afirma que en él "la mayoría de las veces será verosímil la culpa de la empresa”. Esto es más claro si se considera como concibe el requisito cuantitativo que estima también necesario para la concurrencia de la fuerza mayor: la magnitud del hecho, que considera destinada a eliminar la desconfianza sobre la existencia de culpa en el deudor. ExNER, Adolf, cit. (n. 40), pp. 117 y 149.

${ }^{52}$ Cfr. Trimarchi, Pietro, Il caso fortuito, cit. (n. 38), p. 838.

${ }^{53}$ Así lo afirma Del Olmo, según quien "Exner coloca la primera piedra de la llamada responsabilidad por riesgo de empresa”. Del Olmo Guarido, Natalia, cit. (n. 33), p. 45. En relación con este punto se pronuncia también Antonmattei, afirmando que la exterioridad material, que reconoce surgida con Exner, deviene en instrumento de objetivación de la responsabilidad civil. Antonmattei, Paul Henri, cit. (n. 5), p. 26. También lo reconocen, Trimarchi, Pietro, Il caso fortuito, cit. (n. 38), p. 838; Anelli, Franco, cit. (n. 8), p. 167. 
continuar la evolución iniciada por Exner hacia una concepción objetiva de dicha responsabilidad ${ }^{54}$, y por ende, del caso fortuito, objetivación de este último que se expresa, básicamente, en la forma de concebir la exterioridad.

Esta tesis toma como punto de partida la existencia de ciertos riesgos que son inherentes al ejercicio de una actividad empresarial, al derivar de la organización de los diversos medios que su desarrollo implica. Por lo mismo, tales riesgos deben recaer sobre quien tiene el control de su funcionamiento ${ }^{55}$ : el empresario, dando lugar a una responsabilidad objetiva de éste, sin consideración de su conducta, por aquellos incumplimientos que constituyan la verificación de un riesgo comprendido en dicha actividad, siendo posible su exoneración sólo cuando se trate de riesgos extraños a la misma.

De esta forma, la exterioridad del caso fortuito es de naturaleza objetiva, pues ya no se determina en relación a la voluntad del deudor, sino que el punto de referencia es el riesgo creado por la realización de una actividad económica organizada calificable como empresa ${ }^{56}$. Ésta, como ordenación de los factores productivos, comprende el conjunto de operaciones desarrolladas y de medios empleados por el deudor para lograr el resultado debido $^{57}$, es decir, todo lo que involucra la organización, preparación y

${ }^{54}$ En Francia Antonmattei afirma que la noción material de la exterioridad de Exner sedujo a los autores franceses partidarios de la teoría del riesgo. AnTONMATTEI, Paul Henri, cit. (n. 5), p. 27.

${ }^{55}$ Betti emplea la expresión riesgo profesional, que define como "aquel riesgo que es inherente a una profesión, y en general, al desarrollo de un actividad peligrosa”, y ubica como ejemplos de ese riesgo el propio de la organización de una empresa, o del mecanismo interno de una industria. Agrega que en razón de ese riesgo profesional responde quien tiene el control sobre dicha organización, pues "en la conciencia social se considera inherente a tal situación de control del poder de previsión o prevención de los riesgos que son inseparables del aparato" (la empresa). BETTI, Emilio, Teoria General de las Obligaciones (trad. cast., Madrid, 1970), pp. 166- 167.

${ }^{56}$ Siguiendo los postulados del análisis económico, Trimarchi entiende como riesgo de empresa aquel que ésta crea y que económicamente puede serle atribuido como parte de sus costos, de modo tal que el caso fortuito es el evento extraño al riesgo creado y económicamente administrable. Trimarchi, Pietro, Il caso fortuito, cit. (n. 38), pp. 840 y 850. Si bien se trata de una definición que el autor propone en sede extracontractual, su razonamiento en el ámbito contractual es similar, pronunciándose a favor de excluir la responsabilidad por causas externas a la organización del deudor, en tanto éste puede influir directamente en la ejecución de la prestación, adoptando medidas idóneas para prevenir el daño. TrimarCHI, Pietro, Sul significato economico dei criteri di responsabilità contrattuale, en RTDPC. (Milano, 1970) 1, p. 521.

${ }^{57}$ ANELli, Franco, cit. (n. 8), p. 168. 
ejecución de la prestación a satisfacción del acreedor ${ }^{58}$. Así, en la noción de empresa se incluyen, por una parte, el conjunto de medios de que se sirve el deudor; así como el objeto y las características mismas de la actividad, la que por su propia naturaleza supone riesgos ${ }^{59}$, los que dependerán del giro concreto desarrollado. Por ejemplo, en una empresa dedicada a la limpieza de prendas de vestir, forman parte del riesgo propio de su actividad, el correcto funcionamiento y buen estado de mantención de las máquinas empleadas en el lavado y planchado de la ropa, de modo que cualquier daño en las prendas de un cliente derivado de un defecto en aquellas no puede calificarse como extraño a la empresa. Algo similar ocurre si se piensa en una empresa constructora, dentro de cuyos riesgos se encuentra, entre otros, la calidad de los materiales empleados en las obras desarrolladas. $\mathrm{O}$ en una empresa que organiza actividades vinculadas con deportes extremos, en que los implementos de seguridad en buen estado son necesarios para la prestación de sus servicios, integrando el riesgo de la misma.

Así, el caso fortuito es ajeno o extraño porque constituye la verificación de un obstáculo que no tiene su origen en el riesgo asociado a la actividad de empresa, sino fuera de ella. El caso fortuito, conforme a esta doctrina, es el límite al riesgo de empresa ${ }^{60}$, estableciendo la frontera entre lo que es extraño al riesgo propio de la actividad desarrollada por el deudor para cumplir y lo que es inherente a la misma ${ }^{61}$. En esta concepción objetiva, la exterioridad se convierte en un elemento determinante, e incluso según algunos ${ }^{62}$, suficiente por sí solo para configurar el caso fortuito, llegando a descartarse las nociones de imprevisibilidad e irresistibilidad. Esto, porque se concluye que basta, para la exoneración, que el incumplimiento no tenga su origen en el riesgo de la empresa. Éste es el fundamento la responsabilidad contractual, de modo tal que todo hecho que afecte el cumplimiento y que no corresponda a dicho riesgo no puede atribuir responsabilidad al deudor, sin necesidad de indagar sobre la previsibilidad o resistibilidad del evento en cuestión ${ }^{63}$.

\footnotetext{
${ }^{58}$ No se trata del círculo industrial entendido únicamente en un sentido material o espacial, como postulaba Exner.

${ }^{59}$ Anelli, Franco, cit. (n. 8), p. 168.

${ }^{60}$ Anelli, Franco, Ibid, p. 167; Trimarchi, Pietro, Rischio e responsabilità oggettiva (Milano, 1961), p. 199. Destacando el doble punto de referencia-culpa y riesgo- del caso fortuito en el tiempo, Antonmattei, Paul Henri, cit. (n. 5), p. 32; Del Olmo Guarido, Natalia, cit. (n.33), p. 190; Cottino, Gastone, Voz caso fortuito, cit. (n. 36), p. 378.

${ }^{61}$ Anelli, Franco, cit. (n. 8), p. 162.

${ }^{62}$ Ibíd.

${ }^{63}$ Anelli explica la suficiencia de la exterioridad afirmando que las exigencias de imprevisibilidad e irresistibilidad son sustituidas por la determinación de lo que es o no ajeno al deudor. ANELli, Franco, cit. (n. 8), p. 162.
} 
Sin embargo, aun cuando una concepción objetiva de la exterioridad sea deseable, y al mismo tiempo, se reconozca como una realidad indesmentible la existencia de ciertos riesgos derivados de toda actividad de empresa, y en general, de cumplimiento ${ }^{64}$, no pueden perderse de vista los otros dos requisitos que también forman parte del concepto de caso fortuito. Por ello, acoger esta concepción objetiva de la exterioridad planteada por la teoría del riesgo de empresa, puede resultar excesivo, en la medida que el caso fortuito termina reduciéndose exclusivamente al elemento de la ajenidad. Por el contrario, puede darse a la exterioridad un contenido objetivo que la distinga de los dos elementos restantes de la noción de caso fortuito, pero que no implique negarlos. En este sentido, cabe considerar el surgimiento en el derecho comparado, particularmente el español, de opiniones doctrinales que si bien postulan una noción objetiva de la exterioridad, vinculada con la idea de riesgos, la coordinan adecuadamente con la imprevisibilidad y la irresistibilidad propias del caso fortuito ${ }^{65}$. Se trata, por lo demás, de interpretaciones que consideran los principios informantes del derecho uniforme de los contratos, cuya noción de exterioridad constituye un modelo de relevancia para construir la exigencia en nuestro ordenamiento.

Éste es pues, el tratamiento que en los sistemas continentales se ha dado a la exterioridad del caso fortuito. Como se puede advertir, las dos formas de concebir el requisito influyen en la distinción, que habitualmente se plantea, entre un concepto subjetivo y uno objetivo de caso fortuito. En efecto, el primero se relaciona directamente con la concepción sicológica de la exterioridad, que se traduce en la ausencia de culpa del deudor como consecuencia de la imprevisibilidad y de la irresistibilidad del hecho; mientras que cuando la exterioridad es entendida en el último

${ }^{64}$ De hecho, lo que en definitiva subyace al planteamiento del riesgo de empresa es la idea de que toda actividad -no sólo empresarial- a través de la cual un deudor pretenda dar cumplimiento a una obligación, es susceptible de generar una serie de riesgos asociados a su realización, cuyo conjunto puede calificarse, como lo hace ANELLI, Franco, cit. (n. 8), pp. 160 y 165 n. 12, como riesgo típico.

${ }^{65}$ Se trata de una interpretación que pretende una objetivación de la responsabilidad contractual, y que se realiza en base a una regulación bastante similar a la nuestra, reconociendo la necesidad de adaptarla a las necesidades y realidad existente hoy en el tráfico. En tal tarea el requisito de la exterioridad es una herramienta importante. En esta corriente doctrinal se ubican, entre otros: PANTALEÓN, Fernando, $E l$ sistema de responsabilidad contractual. Materiales para un debate, en ADC. 44(1991) 3; Díez-Picazo, Luis, Fundamentos del Derecho Civil Patrimonial II: Las relaciones obligatorias $^{6}$ (Madrid, 2008); Del Olmo Guarido, Natalia, cit. (n. 33), p. 197; Bercovitz Rodríguez-Cano, Rodrigo (director), Manual de Derecho civil. Obligaciones (Madrid, 2003), pp. 123 ss. 
sentido planteado, en relación con el riesgos propios de la empresa del deudor, el concepto de caso fortuito se califica como objetivo.

\section{Derecho uniforme: ajeneidad a la esfera de control del deudor.}

Dentro de este derecho, la idea de exterioridad de la causa de exoneración se encuentra fuertemente determinada por la responsabilidad objetivada $^{66}$ que se consagra en los diversos cuerpos que lo integran.

Así, en la "Convenicón de Viena" (= CV.) -el principal de los instrumentos que lo conforman, y el único con fuerza vinculante, incluso en nuestro país- el artículo 79,1, que consagra con parámetros bastantes rigurosos $^{67}$ la exoneración de responsabilidad del deudor, establece como primer requisito $^{68}$ para que ella pueda operar, que el incumplimiento se haya debido a un impedimento fuera del control del deudor ${ }^{69}$. Por consiguiente, según la CV. la exterioridad consiste en la ajeneidad del impedimento que ocasiona el incumplimiento a los riesgos cuyo control corresponde al deudor.

Ahora bien, para precisar el contenido del requisito es necesario determinar los riesgos cuyo control corresponde al deudor. Dicha tarea requiere considerar, en primer lugar, que todo deudor, al momento de contratar, realiza una valoración y examen de una serie de factores que pueden incidir en el cumplimiento ${ }^{70}$, análisis de importancia para la

${ }^{66}$ Sin consideración de la culpa como criterio de imputación.

${ }^{67}$ Así lo afirman Honnold, John, Uniform Law for International Sales (3a edición, La Haya, 1999), par. 432.1; Vidal Olivares, Álvaro, Atribución y exoneración de responsabilidad en la compraventa internacional, en RDUAs. 18 (2005)1, p. 70; Stoll, Hans - Gruber, Georg, Article 79, en Schlechtriem, Peter (director), Commentary on the UN Convention the International Sale of Goods ( $3^{\text {a }}$ edición, 1986, trad. inglés, 2006), par. 1.

${ }^{68}$ Honnold se refiere a éste como el primer elemento que debe probar la parte que desea establecer que no es responsable por la falta de cumplimiento. HonNOLD, John, cit. (n. 67), par. 423,4. Los restantes requisitos son la razonable imprevisibilidad del impedimento a la celebración del contrato y la insuperabilidad del impedimento en sí y en sus consecuencias.

${ }^{69} \mathrm{Si}$ bien la versión oficial en castellano emplea la expresión de impedimento "independiente de su voluntad", en general entre los autores hay concordancia en cuanto a que se capta mejor el sentido de la disposición con la expresión de la versión en inglés: "impediment beyond his control". Así lo afirman, Vidal Olivares, Álvaro, Atribución, cit. (n. 67), p. 62 ss.; PICHONNAZ, Pascal, Impossibilité et exorbitante. Étude analytique des obstacles à l' exécution des obligations en droit suisse (Friburgo, 1997), p. 391. Prefiriendo la versión inglesa en vez de la alemana, por razones similares, Stoll, Hans; Gruber, Georg, cit. (n. 67), par. 14.

${ }^{70} \mathrm{~A}$ la individualización de los factores que la parte, que luego es incumplidora, debe valorar al celebrar el contrato se refiere Ponzanelli, Giulio, Articolo 79, en 
configuración de su esfera de control. En efecto, como expresa Stoll ${ }^{11}$, la capacidad para controlar el riesgo por parte del deudor no puede ser juzgada abstractamente y sin referencia al contrato mismo, siendo necesaria una razonable interpretación de lo que las partes entendieron, de modo que el contenido del contrato es de gran relevancia para la determinación de los riesgos cuyo control corresponde al deudor ${ }^{72}$. Sin perjuicio de ello, en la labor de determinación de los referidos riesgos, se debe tener en cuenta también, como el mismo autor destaca, que la formulación del artículo 79 está basada en la idea de que el deudor tiene una esfera típica de control, por la que es básicamente responsable ${ }^{73}$.

BianCA, Cesare (a cura di), Convenzione di Vienna sui contratti di vendita internazionale di beni mobili (Padova, 1992), p. 310, quien la califica como un clásico ejemplo de asignación de riesgos. En igual sentido, en diversas sentencias se ha expresado que la aplicación del artículo 79 se centra en la evaluación de los riesgos que una parte asume cuando celebra el contrato. Así se recoge en algunos de los fallos citados en el Compendio de la UNCITRAL sobre jurisprudencia relativa a la CV. Así por ejemplo, en el caso CLOUT 166, resuelto en Alemania, el 21 de junio de 1996. El supuesto sobre el que se pronuncia el fallo era el de un vendedor que, debido al incumplimiento -en razón de las dificultades financieras que le afectaban- del fabricante que le proveía las mercaderías, no cumplió con las entregas pactadas con su comprador. El tribunal arbitral, junto con destacar la importancia de la distribución de riesgos en el contrato para la aplicación del artículo 79, denegó la exoneración del vendedor afirmando que las dificultades financieras del fabricante eran de responsabilidad del vendedor. También se reconoce expresamente la importancia de la repartición de riesgos del contrato en el caso CLOUT 271, resuelto por el Bundesgerichtshof de Alemania, el 24 de marzo de 1999. Se trata de fallos en que, como se expresa en el Compendio, lo fundamental es determinar si la parte que reclama una exoneración asumió el riesgo del evento que justifica su incumplimiento. Compendio de la UNCITRAL sobre jurisprudencia relativa a la Convención de las Naciones Unidas sobre contratos de compraventa internacional de mercaderías, disponible, así como los fallos aludidos, en www.uncitral.org.

${ }^{71}$ Stoll, Hans, Article 79, en Schlechtriem, Peter (director), Commentary on the UN Convention the International Sale of Goods (2a edición, Oxford, 1986 trad. inglés 1998), par. 7.

${ }^{72}$ Salvador Coderch señala que frecuentemente los términos del contrato describirán el ámbito de control, siendo por ello importante la interpretación del contrato concreto, teniendo en cuenta lo que sería razonable esperar de las partes a partir de las circunstancias del mismo. Salvador Coderch, Pablo, Comentario Artículo 79 CSIG, en Díez- PicAzo y PONCE DE LeÓN, Luis (director), La compraventa Internacional de mercaderías (Madrid, 1998), p. 638. Asimismo, Vidal afirma que la fijación de la extensión de la esfera de control conforme al artículo 79 es un problema de interpretación de la voluntad negocial. VIDAL Olivares, Álvaro, Criterios de atribución de responsabilidad por daños en la Compraventa Internacional de Mercaderías (Tesis Doctoral, Universidad Autónoma de Madrid, Madrid, 1999), p. 493.

${ }^{73}$ STOLL, Hans, cit. (n. 71), par. 20. El autor define la esfera típica como: “A 
El principio central entonces en la CV. es que todo deudor tiene una esfera de riesgos que necesariamente debe controlar y por cuya concreción no puede ser exonerado: un impedimento que corresponda a alguno de dichos riesgos no cumple con la exigencia prevista en el artículo $79,1^{74}$. Dicha esfera se determina, en primer lugar, en base a las estipulaciones del contrato, considerando la asunción de riesgos que éste contiene ${ }^{75}$, sin perjuicio de la necesidad de incorporar también en dicha esfera aquellos riesgos que se desprenden de la propia naturaleza de la relación obligatoria, así como de los usos y prácticas existentes previamente entre las partes, y que por ello competen al deudor. La noción de esfera de control implica,

sphere within which is it objectively possible for, and can be expected of, the promissor to secure the trouble-free passage of the measures necessary to prepare and perform the contract by adopting measures of organization and appropriate controls"; $y$ señala como elementos que integran dicha esfera, en el contexto de la CV: i) Lo que denomina la esfera propia del deudor, dentro de la que ubica sus circunstancias personales, su capacidad financiera, así como lo que derive de la naturaleza y organización de su esfera; ii) Riesgo de adquisición si se trata de ventas genéricas; c) riesgo de utilidad; y iii) Riesgo por su personal propio. Sobre el contenido particular de cada una de estas categorías, así como las posibles excepciones y situaciones problemáticas, como cambios de circunstancias económicas, disputas laborales o intervenciones estatales, véase par. 27 ss. En términos similares, Vidal define la esfera de control según el artículo $79 \mathrm{CV}$. como "aquella que comprende todas las medidas de organización y control apropiado, que razonablemente puede esperarse que el deudor adopte y que son necesarias para la adecuada preparación de la prestación y el cumplimiento". Vidal Olivares, Álvaro, Criterios de atribución, cit. (n. 72), p. 499. Por su parte, y en un sentido similar a Stoll, Pichonnaz destaca que es necesaria la concreción del impedimento para saber si está o no fuera de la esfera de influencia del deudor, aunque igualmente se pueden destacar ciertas hipótesis típicas, entre las que ubica la acción de los auxiliares y empleados del deudor. Pichonnaz, Pascal, cit. (n. 69), p. 391.

${ }^{74}$ Esta es la idea que subyace a la decisión dictada en el caso CLOUT 277, resuelto en Alemania el 28 de febrero de 1997. Un comprador inglés y un vendedor alemán celebran un contrato para el suministro de hierro y molibdeno desde China. El vendedor incumple debido a la falta de entrega del proveedor chino. El tribunal rechaza la alegación de exoneración por parte del vendedor, pues estima que el incumplimiento del proveedor es un riesgo que corresponde a aquel. Se advierte que el supuesto de hecho es similar al del caso CLOUT 166, citado en la nota 282 y que en definitiva en ambos fallos está la idea de una esfera controlada por el deudor, que impide la exoneración por riesgos pertenecientes a la misma, en estos casos, la actuación de un proveedor.

${ }^{75}$ En este sentido cabe destacar, como expresa Salvador Coderch, que la CV recoge la idea anglosajona del contrato como acuerdo de distribución de riesgos entre las partes. Salvador Coderch, Pablo, cit. (n. 72), p. 637. Esta idea, que deriva de una visión práctica del contrato, es fundamental para una formulación de la exigencia de exterioridad del caso fortuito adecuada a las necesidades del tráfico, y constituye un aporte del modelo de responsabilidad consagrado en la CV. 
en definitiva, hacer recaer el daño derivado del incumplimiento sobre la parte que está en la situación más propicia para controlar los riesgos de un incumplimiento ${ }^{76}$. De vital importancia es, entonces, determinar si el deudor estaba en situación de influir o controlar la sobreveniencia del impedimento ${ }^{77}$, lo que dependerá de su actividad concreta en cada caso. Lookofsky afirma que un comerciante razonable debe entenderse en control de su propio negocio ${ }^{78}$. Una función fundamental desempeña en este sentido el modelo de la persona razonable, que provee de un criterio para la definición de aquello que debe estimarse controlable por el deudor, integrando así su esfera ${ }^{79}$.

A partir de lo señalado, puede concluirse que, en la CV., el examen necesario para resolver si se cumple o no el requisito de la exterioridad exige definir si el impedimento que ocasiona el incumplimiento está o no dentro de aquellos riesgos cuyo control puede razonablemente exigirse al deudor, teniendo en cuenta tanto lo acordado en el contrato, como aquello que está efectivamente bajo su dominio según las circunstancias concretas del caso $^{80}$. Por esto se ha afirmado que en la CV. la exoneración está basada en la falta por parte del deudor de un razonable control del riesgo del incumplimiento ${ }^{81}$.

${ }^{76}$ En este sentido se pronuncia Ponzanelli, Giulio, cit. (n. 70), p. 311.

${ }^{77}$ Pichonnaz, Pascal, cit. (n. 69), p. 391.

${ }^{78}$ Bernstein, Herbert; LoOKfosky, Joseph, Understanding the CISG in Europe (La Haya, 1997), p. 107.

${ }^{79}$ En este sentido, Vidal señala que la decisión sobre lo que cae dentro de la esfera de control del deudor se adopta conforme al modelo de conducta de una persona razonable ubicada el lugar del deudor. Vidal Olivares, Álvaro, Atribución, cit. (n. 67), p. 64. Sobre el contenido de dicho modelo, y su aplicación en la CV, vid. EL MISMO, La noción de persona razonable en la Compraventa Internacional, en CABANILlas SÁnCHEZ, Antonio (director), Estudios Jurídicos en homenaje al Profesor Luis Díez-Picazo (Madrid, 2003).

${ }^{80}$ En cuanto a la relevancia de la actividad a desarrollar por el deudor para el cumplimiento, a efectos de definir los riesgos que conforman su esfera, cabe destacar lo señalado por Bonell, quien afirmando la necesidad de interpretar el contrato concreto, afirma la importancia de tener en cuenta aquello que normalmente sucede según el tipo de negocio, considerando las condiciones generales del respectivo sector del tráfico. Bonell, Michael, Force Majeure e hardship nel Diritto uniforme della vendita internazionale, en Diritto del commercio internazionale (Roma, 1990), p. 544.

${ }^{81}$ Así lo afirma expresamente Stoll quien señala: "Article 79 makes the inability to control a risk a general principie of exemption”, idea que según el autor aparece claramente en la expresión "impediment beyond his control" de la versión inglesa del artículo 79. STOLL, Hans, cit. (n. 71), par. 6. Lo mismo destaca Vidal, quien señala que en la CV. "Se consagra expresamente el principio de la razonable controlabilidad del riesgo, que hace responsable al deudor por todos aquellos sucesos que correspon- 
Lo expresado en relación con la CV. es válido también para las causas de exoneración previstas en los otros cuerpos normativos que integran el derecho uniforme de los contratos: El artículo 7,1,7 de los Principios de Unidroit; el artículo 8,108 de los PECL.; y el artículo 3,104,1 del DCFR. En efecto, dichas disposiciones -inspiradas precisamente en el artículo 79 de la CV.- recogen como exigencia para la exención del deudor que el incumplimiento tenga su origen en un impedimento ajeno a su control ${ }^{82}$. El contenido sustancial del requisito es el mismo que se aprecia, según lo señalado, en la causa de exoneración de la $\mathrm{CV} .{ }^{83}$.

Así, se puede apreciar que en el derecho uniforme existe -utilizando la terminología empleada en los derechos continentales- una concepción objetiva de la exterioridad, entendida como la ajeneidad del hecho causante del incumplimiento a los riesgos comprendidos en la esfera de control del deudor, por la cual éste asume una responsabilidad absoluta. De esta forma, la exoneración sólo puede situarse fuera de aquella, siempre que el impedimento cumpla además con los restantes requisitos previstos en el artículo 79,1: su razonable imprevisibilidad a la celebración del contrato y su insuperabilidad, en sí mismo y en sus consecuencias, exigencias que ponen de manifiesto que el deudor no ha podido controlar el obstáculo respectivo, y confirman que la exoneración en la $\mathrm{CV}$. se funda en definitiva en la falta de control del riesgo del incumplimiento.

\section{REFORMULACIÓN DE LA EXTERIORIDAD EN EL "CÓDIGO CIVIL" CHILENO: AJENEIDAD DEL HECHO AL ÁMBITO DE RIESGOS DE INCUMPLIMIENTO FIJADO POR EL CONTRATO}

Habiendo examinado la concepción de la exterioridad en nuestro derecho y en el ámbito comparado, es posible proponer una reformulación de

dan a la realización de un riesgo cuyo control le fue asignado por el contrato o la Convención”. Vidal Olivares, Álvaro, Atribución, cit. (n. 67), p. 61.

${ }^{82}$ Lo mismo se observa en el anteproyecto español de modernización del Derecho de obligaciones y contratos, en cuyo artículo 1209 se consagra la causa de exoneración del deudor, disponiéndose como primer requisito: "Que el incumplimiento haya obedecido a un impedimento ajeno a su voluntad y extraño a su esfera de control".

${ }^{83}$ En particular, sobre el artículo 7.1.7 de los Principios de Unidroit, puede consultarse: Morán Bovio, David, Incumplimiento, en Morán Bovio, David (director), Comentarios a los Principios de Unidroit para los Contratos del Comercio Internacional (Navarra, 2003); PERILLO, Joseph, Force majeure and hardship under Unidroit principles, en TJCL. 5 (1997), pp. 5-28. Sobre el artículo 8.108 de los PECL.: Lando, Ole - Beale, Hugh, Principios de Derecho contractual Europeo. Los trabajos de la Comisión de Derecho contractual europeo (trad. cast., Madrid, 2003); Díez-Picazo, Luis, Roca Trías, Encarna, Morales Moreno, Antonio Manuel, cit. (n. 17). 
la misma. A mi juicio, es posible reinterpretar este requisito asignándole un significado propio, que contribuya efectivamente al concepto de caso fortuito, y que muestre que éste actúa también como una regla para atribuir responsabilidad al deudor.

La reformulación propuesta consiste en dar a la exterioridad un significado objetivo, pero sin que ello se exprese en términos estrictamente causales, y tampoco en un sentido que termine reduciendo el caso fortuito a este solo elemento ${ }^{84}$. Por el contrario, el contenido propio de la exterioridad puede definirse simplemente reconociendo una función que, desde un punto de vista práctico, desempeña todo contrato: distribuir una serie de riesgos entre las partes, dentro de los cuales se encuentra el del incumplimiento. Tal función no es extraña a nuestro ordenamiento, y permite elaborar, a partir del propio contrato y de su interpretación, una nueva forma de concebir la exterioridad.

Ahora bien, desde ya es necesario dejar establecida una premisa fundamental. La idea de ajeneidad del caso fortuito se desprende, en principio, de su propia naturaleza fáctica. Se trata de un hecho, es decir, de un acontecimiento que es físicamente distinguible de la conducta del deudor y que se opone al cumplimiento de la prestación debida, alterando el escenario en que se celebró el contrato ${ }^{85}$. Cuando el artículo 45 CC. lo define como "el imprevisto a que no es posible resistir", aunque no lo dice expresamente, está aludiendo a un hecho ${ }^{86}$ que afecta al deudor en

${ }^{84}$ Como ocurre en las tendencias que definen la exterioridad en relación con el riesgo de empresa, y según las cuales, la ajeneidad a dicho riesgo basta para la calificación de caso fortuito.

${ }^{85}$ Rodríguez Grez, Pablo, cit. (n. 14), p. 181. El autor pone énfasis en que se trata de un hecho que introduce una transformación al escenario en que se contrajo la obligación.

${ }^{86} \mathrm{Y}$ así se desprende también de las propias opiniones doctrinales. Nuestros autores reiteradamente aluden al caso fortuito como hecho, evento o acontecimiento. Y lo mismo ocurre en la jurisprudencia, pues en diversos fallos nuestros tribunales se refieren también al caso fortuito empleando dichos términos. Cabe citar, a modo de ejemplo, Sentencia Corte Suprema, de 2 de mayo 1963, en RDJ. 60 (1963), sec. 1a , p. 59; Sentencia Corte Suprema, de 9 de septiembre de 1937, en RDJ. 35 (1937), sec. $1^{\text {a }}$, p. 31. En España, Badosa Coll afirma que el carácter de suceso -como lo denomina el artículo 1105 del Código Civil español- o acontecimiento que tiene el caso fortuito implica ajeneidad material respecto del deudor y de la cosa debida. Badosa, Ferrán, Artículo 1105, en Paz-Ares, Cándido y otros (director), Comentarios del Código Civil (Madrid, 1993), II, p. 43. Y dentro de la corriente doctrinal ya mencionada que busca objetivar la responsabilidad contractual y con ella, la noción de caso fortuito, son varios los autores que fundan la exterioridad como exigencia del mismo, en la expresión "suceso" que emplea el artículo 1105 del Código Civil. Así, Díez-Picazo señala que no puede pasar inadvertido que el Código hable de su- 
su actividad de cumplimiento. Ello permite distinguir en el plano de la realidad material entre el deudor y el obstáculo que le sobreviene, lo que, al menos preliminarmente, conduce a la idea de ajeneidad respecto de éste, impidiendo, por ejemplo, que un hecho del propio deudor pueda calificarse como caso fortuito ${ }^{87}$. Sin embargo, esa sola independencia fáctica no es suficiente para dar sentido a la exterioridad ${ }^{88}$. Su definición requiere con-

cesos, y agrega que ello supone hechos exteriores al marco de control del deudor, postulando una interpretación del artículo 1105 en sentido objetivo. Díez-PicAzo, Luis, Fundamentos, cit. (n. 65), p. 727. Igual interpretación del término suceso propone Pantaleón, quien sosteniendo una exégesis del artículo 1105 coincidente con lo previsto en el artículo 79 de la CV., señala que "la palabra suceso del artículo 1105 CC. significa impedimento ajeno al ámbito de control del deudor”, PAnTAleón, Fernando, El sistema de responsabilidad contractual, cit. (n. 65), p. 1065. También funda en la expresión suceso el carácter extraño del hecho, TorRalba, Orencio, $L a$ responsabilidad por los auxiliares en el cumplimiento de las obligaciones, en ADC. 24 (1971) 4, p. 1154.

${ }^{87}$ Por esta razón, no comparto la opinión de aquellos autores nacionales que fundan la exterioridad en la parte final del inciso segundo del artículo 1547 CC., según el cual el caso fortuito no exonera si ha sobrevenido por culpa del deudor. La atribución de dicho fundamento legal a la exigencia en estudio, se entiende solamente bajo una concepción estrictamente subjetiva de la exterioridad, esto es, como equivalente a la ausencia de culpa del deudor respecto del evento, la que debe descartarse por las razones expuestas precedentemente. Por lo demás, dicha norma es imprecisa en sus términos, pues la existencia de culpa de parte del deudor en relación con el hecho que afecta el cumplimiento impide en definitiva hablar de caso fortuito. Aun cuando éste no es estrictamente sinónimo de ausencia de culpa, sí supone no concurrencia de ella, pues las exigencias de imprevisibilidad e irresistibilidad se miden en base a la diligencia exigible al deudor. Por ello, si ésta falta en las tareas de previsión y resistencia al evento por parte del deudor, impediría calificar a este último como caso fortuito. En nuestra doctrina, Abeliuk se refiere a la expresión de la norma aludida del artículo 1547 como poco exacta, y afirma que "si hay culpa no hay caso fortuito". Abeliuk Manasevich, René, cit. (n. 17), p. 532. Cabe destacar en este sentido una sentencia en que se rechaza la alegación de caso fortuito respecto de un incendio que destruyó el inmueble arrendado, afirmando que el deudor no cumplió como buen padre de familia con el cuidado y conservación del mismo, por lo que en caso alguno se configura la causa de exoneración. Sentencia de primera instancia de fecha 28 de junio de 2002, confirmada por la Corte de Apelaciones de Concepción por sentencia de fecha 23 de septiembre de 2003, disponible en www.legalpublishing.cl, número identificador 29200.

${ }^{88}$ Aunque sí basta para que el hecho del deudor quede excluido de la calificación de caso fortuito, al no ser ajeno ni siquiera en esta acepción estrictamente material. Por lo demás, así parece ser según nuestro legislador, como se desprende de los artículos 1678, 2187 y 2231 CC., en que al deudor se le hace responsable por el hecho propio, sin perjuicio de que se limite el alcance de la misma, al extenderse solamente al precio de la cosa. 
siderar el contenido del contrato: el caso fortuito debe ser un hecho ajeno al deudor, y más concretamente, a los riesgos que éste asume al celebrarlo, y cuya verificación no puede, por tanto, eximirlo de responsabilidad.

Para entender a cabalidad lo recién expresado, es indispensable hacer referencia a la función de distribución de riesgos que todo contrato desempeña. Ello demostrará que atendiendo al contenido de este último se puede reformular la noción de exterioridad.

\section{El contrato como mecanismo de distribución de riesgos.}

a) El contrato como intercambio económico: base de su función de distribución de riesgos. La asociación entre las nociones de contrato y riesgo, deriva de que aquel constituye un medio para el intercambio económico ${ }^{89}$, es decir, una herramienta para el tráfico de bienes y servicios en el mercado, lo que supone la exposición al riesgo de toda iniciativa de ese tipo ${ }^{90}$, especialmente teniendo en cuenta que el contrato comúnmente implica una actuación posterior de cumplimiento, que además puede extenderse en el tiempo. Esto último trae aparejada, como es lógico, la posibilidad de que una serie de contingencias puedan incidir sobre las partes o sus prestaciones durante la ejecución de las mismas, surgiendo con ello la idea de riesgo, entendido en su acepción corriente: como eventual proximidad de un daño ${ }^{91}$.

Se trata de un planteamiento que deriva simplemente de reparar en la dimensión económica del contrato, es decir, de una apreciación práctica

${ }^{89}$ En relación con esta idea cabe citar las siguientes palabras de Baraona, destacando la importancia de considerar este aspecto del vínculo contractual: "Una de las precisiones más importantes que se han hecho en el Derecho contemporáneo es el énfasis puesto en la comprensión del contrato como una realidad económica (función de cambio, operación económica, explicable como un acuerdo en torno a una determinada distribución de riesgos”. BARAONA GONZÁLEZ, Jorge, El retraso en el cumplimiento de las obligaciones (Madrid, 1998), p. 198.

${ }^{90}$ En este sentido se expresa en Italia Bessone, agregando que tanto oferta como aceptación parten de una valoración de las circunstancias y de razonables previsiones acerca del éxito del negocio, no obstante lo cual las circunstancias se transforman incesantemente, de modo que un evento que altera los presupuestos siempre puede perjudicar dicho éxito. BESSONE, Mario, Adempimento e rischio contrattuale (Milano, 1969), p. 1.

${ }^{91}$ Según la RAE la palabra riesgo se define como contingencia o proximidad de un daño. El término riesgo, como expresa un autor, indica en el lenguaje usual una situación de incerteza o eventualidad, implica la idea de un sacrificio ligado a la verificación de un acontecimiento, noción abstracta que se concreta por referencia a específicos tipos de sucesos y sacrificios amenazados. Orlando, Salvatore, Rischio e vendita internazionale (Milano, 2002), pp. 15-16. 
del mismo, idea muy presente en la tradición anglosajona ${ }^{92}$, que ha sido adoptada por el derecho uniforme de los contratos, y que también es necesario considerar en los sistemas jurídicos continentales, pues no es sino la constatación de una realidad evidente ${ }^{93}$. El contrato no puede ser entendido en su esencia si se le examina sólo como noción jurídica ${ }^{94}$, sino que debe ser apreciado en conexión con la realidad en que se inserta y dentro de la cual desempeña una función concreta: ser una herramienta para la satisfacción de intereses patrimoniales concretos de las partes, de modo que en definitiva constituye la formalización jurídica de una operación económica ${ }^{95}$.

${ }^{92}$ Atiyah destaca esta circunstancia en el Derecho inglés, afirmando respecto del Derecho de contratos que "is largely concernid with economic exchange"; y agrega luego que "the law of contract gives legal effect to the operation of the market so as to enable business and commercial activities to be carried on efficiently". ATIYAн, Patrick Selim, An Introduction to the Law of Contract (Oxford, 1995), pp. 3 y 35. En sentido similar se pronuncia en Estados Unidos Farnsworth, quien destaca la importancia que para el Derecho de contratos tiene el intercambio, afirmando: "The main concern of the law of contracts, then, is with exchanges", y resalta luego también la relevancia de los intercambios para las economías de libre mercado. FARnSwOrTH, E. Allan, Contracts (2a edición, Boston, 1990), pp. 4 ss. Esta idea también es un planteamiento fundamental para los postulados del análisis económico del Derecho. Así, Torres López -en sentido similar a lo expresado por Atiyah- afirma que la función del Derecho de contratos es hacer efectivos y eficaces los intercambios, refiriéndose al contrato como un intercambio futuro basado en el cumplimiento de una promesa. TORRES López, Juan, Análisis económico del Derecho. Panorama doctrinal (Madrid, 1987), p. 56.

${ }^{93}$ Como expresa Morales Moreno: "El contrato es regla o deber ser, pero también se asienta sobre una realidad concreta". Morales Moreno, Antonio Manuel, Articulo 35, en Díez- PicAzo y Ponce de León, Luis (director), La compraventa internacional de mercaderías. Comentario de la Convención de Viena (Madrid, 1998), p. 290.

${ }^{94}$ Así se expresa en Italia Roppo, quien afirma además que si bien el contrato es un concepto jurídico, un término que sintetiza una serie de principios de Derecho, como todo concepto jurídico, refleja una realidad de intereses, de relaciones, de situaciones económico-sociales frente a los cuales cumple una función instrumental. Por ello, según el autor: "Per conoscere davvero il concetto di cui ci ocupiamo [el de contrato] appare necessario prendere in atenta considerazione la realtà economicosociale che lo sostanzia, e di cui esso rappresenta la traduzione scientifico-giuridica: tutte quelle situazione, quei rapporti, quegli interessi reali che vengono in gioco là dove si parla di contratto" (lo destacado es del autor). Roppo, Enzo, Il contratto (Bolonia, 1977), p. 9.

${ }^{95}$ Ibíd, p. 11. En España, Gavidia destaca esta circunstancia y se refiere al contrato como regulación de una operación económica, afirmando: "En la realidad de los fenómenos económicos más que negocios jurídicos o, incluso, que contratos hay operaciones económicas que tienen por objeto el intercambio de bienes o la prestación de servicios". Según el autor a ellas se agregan las normas jurídicas. GAVIDIA, Julio, Presuposición y riesgo contractual, en ADC. 40 (1987) 2, pp. 540 y 584. 
Si se considera que al contrato le subyace en la práctica un intercambio económico, y que supone el despliegue, en un momento posterior a su celebración ${ }^{96}$, de una cierta actividad destinada a concretar dicho intercambio, y con éste, los intereses involucrados, resulta claro que dicha concreción queda sujeta a una serie de eventualidades. Ello hace evidente la estrecha vinculación que existe entre contrato y riesgos.

De esta forma, la noción de riesgo en el plano jurídico-contractual apunta a aceptar la posibilidad de que la finalidad última perseguida con el contrato - la satisfacción de los intereses de las partes- no se concrete, como consecuencia de diversas circunstancias que pueden presentarse a lo largo de la vigencia del vínculo negocial. El factor temporal juega en este sentido un papel determinante, pues el futuro lleva en sí mismo la idea de incerteza ${ }^{97}$, existiendo por ello la posibilidad de que la utilidad pretendida por las partes con el contrato no se haga realidad.

La contratación implica entonces una serie de riesgos, cuya repartición realizan, en primer lugar, las propias partes con su acuerdo de voluntades. En el mismo contrato, éstas proceden a una distribución de los diversos riesgos asociados a la operación económica que aquel envuelve ${ }^{98}$, y sólo a

${ }^{96}$ En la doctrina nacional, Barros Bourie reconoce la proyección hacia el futuro de la vinculación contractual cuando afirma que todo contrato envuelve una promesa, que genera confianza en el acreedor. Barros Bourie, Enrique, La diferencia entre "estar obligado" y "ser responsable" en el Derecho de los contratos, en CORRAL TALCIANI, Hernán - Rodríguez Pinto, María Sara (coordinadores), Estudios de Derecho Civil (Santiago, 2006), II, p. 746.

${ }^{97}$ En este sentido, Posner afirma que un contrato compromete a las partes a determinadas acciones en el futuro, siendo éste incierto y destaca que la no simultaneidad en el intercambio genera el peligro de que se presenten contingencias imprevistas. Posner, Richard, Análisis económico del Derecho (trad. cast., México, 1998), pp. 90 y 103. Por su parte, y poniendo énfasis en el factor temporal, Pichonnaz afirma: “Un contrat qui n'est exécuté inmédiatement peut prendre naissance dans un certain contexte de faits et être exécuté dans un contexte qui s'est modifié". El autor destaca que si bien al contratar toda parte debe hacer una cierta planificación en relación al cumplimiento de su prestación, ésta siempre se caracteriza por un cierto grado de incertidumbre en cuanto a la realización de los hechos planificados. Pichonnaz, Pascal, cit. (n. 69), pp. 5 y 9.

${ }^{98}$ Es así como en el Derecho inglés Treitel afirma que "one of the principal purposes of contract as a legal and commercial institution is precisely to allocate the risks of such events". Treitel, G.H, Frustration and force majeure (Londres, 1994), par. 1-001. En sentido similar se pronuncia Atiyah, quien afirma que " a contract is primarily a risk-allocation device”. Ат̈уан, Patrick Selim, cit. (n. 92), p. 215. Por su parte, Posner afirma que una de las funciones de los contratos es el desplazamiento de riesgos, proveyendo así una forma de aseguramiento, en tanto, como se verá luego, la asignación de los mismos según el análisis económico del Derecho es más eficiente si se atribuyen a aquella de las partes que sea el asegurador más barato. 
falta de regulación convencional, el derecho dispositivo entra a desempeñar dicha función, lo que se aprecia claramente en sede de responsabilidad por incumplimiento contractual.

b) El riesgo que interesa: el de incumplimiento. Su distribución por las partes en el contrato. De acuerdo a lo señalado, la celebración de un contrato involucra la distribución de ciertos riesgos entre las partes. Ahora bien, la expresión riesgos se ha empleado hasta aquí de modo muy amplio, aludiendo a la simple posibilidad, existente al momento de la celebración del contrato, de la no consecución de los fines perseguidos por las partes con el mismo. Esta eventualidad puede calificarse como riesgo contractual en sentido amplio: el riesgo de insatisfacción de los intereses de las partes ${ }^{99}$. Sin embargo, esta idea general de riesgo asociada al contrato es susceptible de concretarse de diversas formas, según cual sea en particular la amenaza que penda sobre dicha satisfacción. La posibilidad de insatisfacción puede provenir, por ejemplo, del incumplimiento por el deudor, cualquiera sea la causa; de una alteración de las circunstancias habidas al momento de contratar que afecta el equilibrio económico de las prestaciones pactadas ${ }^{100}$; así como de la imposibilidad de cumplimiento que extingue la obligación de una de las partes ${ }^{101}$. En este último supuesto, además, puede presentarse lo que puede denominarse como el problema del riesgo contractual en sentido restringido o periculum obligationis: determinar la suerte de la contraprestación, si se trata de un contrato sinalagmático ${ }^{102}$.

${ }^{99}$ En este sentido, cabe tener en cuenta lo sostenido por Gavidia, quien define el riesgo contractual en sentido amplio como "el peligro de insatisfacción de los intereses o de la frustración de las expectativas que una o ambas partes habían pretendido realizar con la puesta en marcha de la operación económica regida por el contrato, como consecuencia de ciertas circunstancias o de la sobreveniencia de ciertos eventos alteradores del programa económico de los contratantes" GAVIDIA, Julio, cit. (n. 95), p. 584 .

Alpa, por su parte, en relación con este punto expresa que el riesgo contractual alude a diversos tipos de incerteza y por lo tanto, a diversas consecuencias, señalando como uno de los tipos de riesgo posibles, el que aquí interesa: el del incumplimiento. Alpa, Guido, Rischio contrattuale, en CIE. 2 (1986), p. 630.

${ }^{100}$ ALPA, ibíd., menciona como una clase concreta de riesgo contractual, la que deriva de trastornos de la economía original del negocio.

${ }^{101}$ En todos estos casos hay un peligro para la consecución de los fines perseguidos por las partes. Cada uno de dichos supuestos afecta de diversa forma el éxito del negocio y constituye por lo tanto un riesgo contractual en sentido amplio.

${ }^{102} \mathrm{Al}$ respecto, es necesario tener presente que el término riesgo está lejos de contar con un significado unívoco en el Derecho. Por el contrario, es usado en muy diversos sentidos. Como destaca en nuestro país Elorriaga, al referirse a la noción de riesgo en el plano jurídico "la expresión riesgo no siempre tiene el sentido unitario 
Ahora bien, dentro de esta acepción amplia de riesgo contractual, el peligro concreto que interesa para construir la noción de exterioridad en

que se pudiera esperar, revistiendo significaciones y alcances harto diversos dependiendo del ámbito en el que ella sea utilizada”. Elorriaga De Bonis, Fabián, Teoría de los riesgos, en Estudios sobre reformas al Código Civil y Código de Comercio (Santiago, 2002), p. 14. Ahora bien, en los sistemas continentales es habitual el empleo de la expresión en relación con la denominada teoría de los riesgos, que busca determinar el efecto que la extinción por imposibilidad de la obligación de una de las partes de un contrato bilateral acarreará sobre la obligación correlativa. Se habla así del problema de los riesgos, aludiendo con ello a la necesidad de establecer si el acreedor de la obligación extinguida deberá cumplir igualmente con su propia prestación, o si, por el contrario, queda liberado de la misma: Se trata en tal caso del riesgo de la contraprestación o periculum obligationis, cuyo significado, como se puede apreciar, es bastante más acotado que la sola idea de insatisfacción del interés contractual, aunque en último término se traduzca en ella. Ello puede explicar que estos supuestos se califiquen como de riesgo en sentido técnico, como lo hace BETTI, Emilio, Teoría General, cit. (n. 55), p. 168; y también Cristóbal MonTEs, Ángel, La imposibilidad sobrevenida de la prestación en la obligación alternativa, en RDPr. (1995), p. 227. Por su parte, Gavidia usa la expresión riesgo en sentido propio para referirse al peligro de que eventos sobrevinientes hagan imposible la ejecución de la prestación de una de las partes o la hagan excesivamente onerosa, de modo tal que, en el caso de imposibilidad, si el contrato es unilateral, el riesgo se traduce para el acreedor en la pérdida del crédito; y si el contrato es sinalagmático, surge la necesidad de establecer el destino de la contraprestación. Gavidia, Julio, cit. (n. 95), pp. 588 y 593. Si bien el autor se aleja de la postura tradicional -por cuanto comprende en la acepción estricta el riesgo de la excesiva onerosidad, al mismo tiempo que admite la procedencia del problema de los riesgos en contratos unilaterales- su planteamiento pone de manifiesto el sentido más restringido con que habitualmente se emplea la expresión riesgos, teniendo como presupuesto una imposibilidad de cumplimiento. Por su parte, si se aprecia el tema exclusivamente desde la perspectiva de la obligación extinguida por imposibilidad, cabe hablar también en un sentido estricto de riesgo de la prestación, que recae sobre el acreedor de la misma. Sobre el contenido de la llamada teoría de los riesgos véase también: DE Cossío, Alfonso, Los riesgos en la compraventa civil y mercantil, en RDPr. (1944); ALCÁNTARA SAMPELAYO, José, La prestación del riesgo en la compraventa, en RDPr. (1946); AlONSO PÉREZ, Mariano, El riesgo en el contrato de compraventa (Madrid, 1972). Por otra parte, cabe señalar, asimismo, que otro ámbito en que suele utilizarse la expresión riesgo en el Derecho es en relación con el denominado periculum rei, o riesgo de la cosa, el que sin embargo debe ser distinguido completamente de la noción de riesgo contractual, por cuanto alude al supuesto en que una cosa se destruye o perece, recayendo dichos eventos sobre el dueño de la misma, por aplicación del aforismo res perit domino. Como expresa Elorriaga, en este caso "se trata del concepto de riesgo aplicado exclusivamente a la propiedad y a los Derechos reales”, Ibíd, p. 15. Se trata de una regla cuya aplicación no tiene en consideración que la cosa sea objeto de una obligación, y, por ello, como expresa Gavidia, no plantea cuestión alguna de riesgo contractual, Ibid, p. 591. 
el caso fortuito, es lo que puede llamarse el riesgo del incumplimiento, que se vincula directamente con la cuestión de la responsabilidad. Entre todos los riesgos existentes al momento de contratar, se encuentra la posibilidad de que no se verifique el cumplimiento fiel y oportuno por parte del deudor, generando con ello daños al acreedor afectado. Si esa eventualidad se concreta, se debe determinar de cargo de cuál de las partes deber ser puesto dicho riesgo: si de la parte deudora, debiendo ésta resarcir el daño causado al acreedor con la inejecución; o si por el contrario, corresponde al acreedor, quien debe soportar el daño derivado de la falta de cumplimiento, sin poder reclamar indemnización. De esta forma, resulta que el problema del incumplimiento -y por consiguiente, el de la responsabilidad- es en definitiva una cuestión de distribución de riesgos: si la respuesta es la primera de las alternativas descritas, implica que el deudor debe ser calificado como responsable de la falta de cumplimiento, con el subsecuente deber de indemnizar, correspondiéndole así el riesgo del incumplimiento. Si por el contrario, se concluye que el evento que afectó el cumplimiento no era de cargo del deudor, éste quedará exonerado de responsabilidad, y ello se traduce en que el riesgo del incumplimiento pesa en definitiva sobre el acreedor ${ }^{103}$.

${ }^{103}$ En Italia, Roppo afirma que el problema de la responsabilidad por incumplimiento es un "problema di ripartizione tra i contraenti del rischio conesso agli eventi che sopravvengono tra il momento della conclusione del contratto e il momento della sua esecuzione" y en relación al contenido de dicho riesgo, señala que éste "si traduce nel quesito se le perdite economiche che una parte subisce per effetto della mancata realizzazione dell'affare, o di una sua realizzazione solo imperfetta, devono essere definitivamente sopportate da questa parte, ovvero devono essere trasferite all'altra parte, cui ne venga imputata la responsabilità e perciò l'obbligo di risarcirle". Destaca además que se trata de un riesgo cuyo contenido es distinto a aquel que se expresa en términos de mantener o perder el Derecho a la contraprestación. Roppo, Enzo, $I l$ contratto, cit. (n. 94), p. 243. En igual sentido se pronuncia luego El MISMO, Obbligazioni e contratti, en BESSONE, Mario (a cura di), Casi e questioni di diritto privato. Obbligazioni e contratti. Responsabilità civile (Milano, 1987), III p. 113. En sentido similar se pronuncia Castrovinci, quien expresa que la cuestión de la responsabilidad contractual se relaciona con la distribución de riesgos, CASTROVINCI, Dario, Il problema della inesigibilità della prestazione, en GC. (1988) 2, p. 346. En España, en relación con esta idea Llamas Pombo afirma que cuando se produce la exoneración del deudor por caso fortuito el riesgo de la frustración del interés del acreedor se atribuye a éste y no al deudor, Llamas Pombo, Eugenio, Artículo 1105, en Pasquau Liaño, Miguel (director), Jurisprudencia civil comentada. Código Civil (Granada, 2000), II, p. 1845. En igual sentido, Morales Moreno, Antonio Manuel, Artículo 35, cit. (n. 93), p. 290. Con dicha afirmación los autores coinciden en la idea de distribución del riesgo del incumplimiento subyacente a la responsabilidad contractual. Por su parte, cabe también tener en cuenta que en los sistemas anglosajones -precisamente por 
De ahí entonces que uno de los principales riesgos que surgen y se distribuyen al contratar es el del incumplimiento, y su relevancia se manifiesta en que su reparto determina las consecuencias en el plano de la responsabilidad por la falta de cumplimiento. Por esta razón, resulta trascendental determinar cómo se produce dicha distribución. En relación con esto, ya señalé que el primer instrumento en que se advierte el reparto del riesgo, en este caso, del incumplimiento es el propio contrato ${ }^{104}$. Como es lógico, las partes son las primeras llamadas distribuir los riesgos de incumplimiento asociados al contrato que celebran ${ }^{105}$. De esta forma, éste aparece como un instrumento que refleja los riesgos asumidos por cada una, en él se contiene la repartición de las ventajas y desventajas que las partes han previsto ${ }^{106}$. Y como desde su celebración está latente la posibilidad de que la ejecución del contrato se vea impedida por algún obstáculo, indudablemente ello

la concepción práctica del contrato que se aprecia en ellos- la idea de distribución de ciertos riesgos entre las partes al contratar, especialmente manifestada en caso de falta de cumplimiento, está siempre presente. En concreto, en el Derecho inglés la denominada "doctrine of frustration" se considera como un medio para dividir entre las partes las pérdidas ocasionadas por los eventos sobrevinientes. Así lo afirma Treitel, quien distingue entre "performance risk" y "payment risk" como los riesgos divididos por la "doctrine of frustration": debido al efecto de ésta, que implica el término total y automático del contrato, el acreedor carga con el primer riesgo, ya que el deudor es excusado de su deber de cumplimiento; y a su vez, el deudor carga con el segundo, en tanto el acreedor es excusado de la contraprestación. Treitel, G.H, Frustration, cit. (n. 98), par. 2-026 y 3-007.

${ }^{104}$ En este sentido, Baraona expresa: "Es evidente que el incumplimiento es un riesgo al que las partes están expuestas y sobre el cual también debieran prever las consecuencias”. BARAONA GONZÁleZ, Jorge, El retraso, cit. (n. 89), p. 199.

${ }^{105}$ En relación con esta idea se presenta la noción del contrato perfecto del análisis económico del Derecho, que según Ott y Schäfer, sería aquel en que las partes han distribuidos e imputado todos los riesgos asociados a su ejecución. SCHÄFER, Hans-Bernd - Отт, Claus, Manual de análisis económico del Derecho civil (Madrid, 1991), pp. 261 ss. Con dicha idea queda en evidencia que los originalmente llamados a determinar la distribución de riesgos derivados de la contratación son las propias partes, aun cuando los mismos autores reconocen que los elevados costos de transacción asociados a un contrato de tales características hace muy difícil que ello se verifique.

${ }^{106}$ AlPa, Guido - Bessone, Mario - Roppo, Enzo, Rischio contrattuale e autonomia privata (Napoli, 1982), p. 348. En Chile, Vidal afirma que el contrato es una norma jurídica particular al que las partes someten su conducta, debiendo obrar de acuerdo con las prescripciones en él contenidas. Vidal Olivares, Álvaro, La construcción de la regla contractual en el Derecho civil de los contratos, en RDUCV. 21 (2000), p. 209. Esta afirmación es útil para aclarar que la fuente principal de la distribución de riesgos es el contrato, pues a las estipulaciones contenidas en él quedan sujetas las partes, lo que comprende por supuesto, lo relativo al riesgo del incumplimiento. 
debe ser objeto de las estipulaciones de los contratantes. Éstos, expresa o tácitamente, determinan un determinado ámbito de riesgos que cada uno asume, y cuya eventual concreción deberán necesariamente soportar en razón de dicha asunción, indemnizando al acreedor.

De esta forma, la convención es primordial para la distribución del riesgo del incumplimiento. El contrato determina el límite entre los riesgos que corresponden al deudor y aquellos que son extraños al mismo. En él se define para cada parte un área de riesgos, de modo tal que ningún hecho que afecte el cumplimiento y que tenga su origen dentro de dicha esfera será ajeno al contratante respectivo. Partiendo de esta idea, es necesario establecer de qué modo se determina ese ámbito de riesgos y cuál es su contenido.

c) Construcción del ámbito de riesgos del contrato. Necesidad de una interpretación integradora del mismo. Según lo señalado, todo contrato fija un ámbito de riesgos que pesa sobre cada una de las partes. Éstas toman a su cargo los eventos que puedan surgir dentro del mismo afectando el cumplimiento, comprometiéndose a controlarlos, y de no ser así, a reparar el daño sufrido por el acreedor en razón del incumplimiento, indemnizándolo. Por esta razón, si la inejecución de la prestación tiene su origen dentro de dicho marco, el deudor no puede alegar la exoneración invocando el caso fortuito, por cuanto no se trataría de un hecho ajeno o externo respecto de él.

Ahora bien, también he dicho que esa distribución del riesgo del incumplimiento se realiza tanto expresa como tácitamente por las partes al contratar. Por ello, para determinar la extensión del ámbito de riesgos asumidos por el deudor, resulta esencial recurrir al contenido del contrato, lo que supone en definitiva interpretarlo ${ }^{107}$, estableciendo el real alcance del acuerdo. Y en dicha labor hermenéutica es fundamental que se preste atención no sólo a las declaraciones explícitas contenidas en el contrato en relación con los riesgos ${ }^{108}$, sino también a aquellas que permitan sobreentender la asunción de determinados riesgos por el deudor ${ }^{109}$. En relación

${ }^{107}$ En este sentido, Anelli afirma que el contrato correctamente interpretado indica los medios que el deudor es obligado a predisponer y el alea al que se expone según la naturaleza de la prestación debida. Anelli, Franco, cit. (n. 8), p. 210.

${ }^{108}$ Como puede ser la descripción en el contrato de determinados eventos que las partes acuerdan poner de cargo de una de ellas. Piénsese, por ejemplo, en un contrato de transporte en que expresamente se acuerde que el cierre de la ruta habitual es un riesgo que corresponde al transportista y que por tanto no podrá alegarlo como caso fortuito.

${ }^{109}$ Según SCHÄFER, Hans-Bernd - OTт, Claus, cit. (n. 105), p. 295, el problema de saber si un riesgo se incluyó implícitamente en el contrato es una cuestión de interpretación. 
con este último punto, adquiere importancia la denominada interpretación integradora del contrato, que permite desarrollar la voluntad contractual ${ }^{110}$, estableciendo objetivamente el alcance de las estipulaciones de las partes y al mismo tiempo las complementa, a partir de la naturaleza y objeto del contrato celebrado ${ }^{111}$.

La necesidad de realizar una interpretación integradora del contrato encuentra su fundamento -y al mismo tiempo, su inspiración- en el principio de buena $\mathrm{fe}^{112}$, que en nuestro derecho se encuentra consagrado en el artículo 1546 CC. Esta regla, informante de todo el derecho contractual, autoriza en sede interpretativa para ir más allá de lo literal ${ }^{113}$ a objeto de fijar el alcance del compromiso contraído por las partes en el contrato, considerando la convención en su totalidad, y comprendiendo como parte de la misma todo lo que derive de la naturaleza de las respectivas obligaciones, y en definitiva, de la finalidad del contrato. No se trata de

${ }^{110}$ Así se expresa Vidal en relación al sentido de la interpretación integradora. El autor distingue entre la determinación de la declaración negocial y de la regla contractual, que operan sucesivamente. La primera busca establecer el alcance de la voluntad de las partes y resulta de aplicar los criterios de interpretación tanto en función declarativa como integradora, debiendo hablarse en tal caso de autointegración; mientras la segunda corresponde a la declaración negocial integrada ahora por las normas dispositivas -labor que se denomina también heterointegración o integración reguladora- y representa el conjunto normativo que regula la relación jurídica correspondiente. Vidal Olivares, Álvaro, La construcción, cit. (n. 106), pp. 209227. La determinación de lo que el citado autor denomina declaración negocial es la que resulta relevante para establecer la distribución de riesgos derivado del contrato, pues implica considerar todo aquello que, aun cuando no aparezca expresamente en el acuerdo de las partes, igual forma parte del mismo.

${ }^{111}$ Como expresa Larenz, frente cuestiones no reguladas expresamente en el contrato, la solución puede deducirse de su sentido y finalidad mediante una interpretación integradora del mismo basada en la buena fe. LARENZ, Karl, Derecho de obligaciones (Madrid, 1958), p. 118.

${ }^{112}$ Ubicando a la buena fe como regla de integración del contrato: BESSONE, Mario, Adempimento e rischio contrattuale, cit. (n. 90), p. 375; Roppo, Enzo, Il contratto, cit. (n. 94 ), p. 259; Montes PenAdés, Vicente, El incumplimiento de la obligación, en Valpuesta Fernández, María del Rosario (directora), Derecho de obligaciones y contratos (2a edición, Valencia, 1995), p. 181; Jordano FraGA, Francisco, Las reglas generales, cit. (n. 7), p. 318; Larenz, Karl, cit. (n. 111), p. 118. Por su parte, Vidal afirma que la norma del artículo 1546 de nuestro Código Civil tiene aplicación tanto en sede interpretativa como de integración normativa del contrato, es decir, por las normas dispositivas. Vidal Olivares, Álvaro, La construcción, cit. (n. 106), p. 216. Por su parte, López Santa María, Jorge, Los Contratos. Parte General (Santiago, 2005), II, pp. 412 ss. también destaca la importancia de la buena fe en la interpretación contractual.

${ }^{113}$ En este sentido se pronuncia BEssone, Mario, cit. (n. 112). 
recurrir sólo a la forma en que las partes han expresado su voluntad, a los términos textuales utilizados por ellas ${ }^{114}$, sino de considerar las circunstancias del negocio concreto ${ }^{115}$, pues todo aquello que precede y rodea la celebración del contrato constituye una herramienta para determinar el verdadero sentido del acuerdo y establecer lo que forma parte del mismo. Como expresa un autor, para el intérprete el contrato es declaración de voluntad y ambiente negocial ${ }^{116}$.

Si se examinan las reglas particulares que nuestro legislador establece en materia de interpretación contractual, se puede apreciar que ellas recogen esta idea ${ }^{117}$. Así, el artículo 1560 CC. ordena tomar en consideración, por sobre lo literal de las palabras, la intención de los contratantes, lo que obliga a atender a la declaración contractual en su conjunto, y no las voluntades aisladas de cada uno de ellos ${ }^{118}$, extrayendo la sustancia de la regulación de intereses establecida por las partes. Asimismo, y con más claridad aún, el artículo 1563 CC. ordena realizar la interpretación que mejor cuadre con la naturaleza del contrato, lo que indudablemente manifiesta la idea de que el contenido del contrato no está dado únicamente por las declaraciones expresas de las partes. Al mismo tiempo, el inciso $2^{\circ}$ de la norma citada dispone que las cláusulas de uso común

${ }^{114}$ En este sentido, López Santa María afirma que "el contrato es un todo complejo, integrado no solamente por la declaración formal, por un texto o por unas palabras, sino que también por otros elementos que no figuran allí y que el intérprete tiene que considerar para estar en situación de llegar a la común intención de las partes”. López Santa María, Jorge, cit. (n. 112), p. 450.

${ }^{115}$ Vidal Olivares, Álvaro, La construcción, cit. (n. 106), p. 224.

${ }^{116}$ Ibíd. El autor señala como parte de las circunstancias que permiten la configuración concreta del negocio, entre otras, los tratos preliminares, los borradores de contratos previos a la conclusión del definitivo, la oferta y sus modificaciones, la aceptación, la información disponible para cada parte, el grado de familiarización entre ellas, el lugar de celebración del contrato.

${ }^{117}$ Sobre las reglas de interpretación del Código Civil, Vidal afirma que entre los criterios que ellas contienen, hay algunos que permiten completar o desarrollar la voluntad de las partes, de modo tal que su aplicación da lugar a una interpretación integradora. Ibíd, pp. 217 y 223.

${ }^{118}$ En este sentido, cabe destacar que Bessone afirma que la interpretación de la común intención de las partes constituye un elemento de juicio para que los tribunales realicen una integración del contenido del negocio. Alpa, Guido - Bessone, Mario - Roppo, Enzo, Rischio contrattuale e autonomia privata, cit. (n. 106), p. 308. Por su parte Larenz afirma que lo que distingue la interpretación integradora de la interpretación de la declaración de voluntad aislada es que no busca averiguar la significación de las expresiones empleadas por el declarante, sino que pretende representar el sentido del contrato como creación intelectual objetiva e inteligible, como norma vinculante para ambas partes. LARENZ, Karl, cit. (n. 111), p. 119. 
se presumen aunque no se expresen, lo que claramente permite incorporar al acuerdo los usos existentes en el sector del tráfico de que se trate, que pueden entenderse comprendidos en el pacto e integrando, por consiguiente, las obligaciones de los contratantes. La vinculación de esta norma con el precepto que recoge el principio de buena fe es evidente, $y$ explica que un autor nacional se refiera a ambas disposiciones como una operación de "complementación del contrato" ${ }^{119}$. Por último, resulta relevante también la norma del artículo 1564, que impone interpretar las cláusulas del acuerdo dándoles el sentido que mejor convenga al co n trato en su totalidad -idea de la consideración del acuerdo en su integridad y no de las declaraciones aisladas- y establece también la posibilidad de que dichas estipulaciones se interpreten conforme a las de otro contrato habido entre las mismas partes y sobre la misma materia, así como por la aplicación práctica que de ellas hayan hecho las partes, con lo que se da cabida a las prácticas que puedan haberse establecido previamente entre ellas. Aparece nuevamente la idea de complemento y desarrollo del contenido contractual, esta vez a partir de aquello que las partes han instaurado como habitual en las relaciones jurídicas previamente existentes entre ellas. En síntesis, las disposiciones aludidas dejan en evidencia que la definición del alcance del contrato autoriza y plantea la necesidad de ir más allá de su contenido expreso y que una labor interpretativa de carácter integradora es indispensable para conocer la extensión real del acuerdo.

A partir de lo expresado, resulta claro que determinar la distribución de riesgos hecha por las partes exige una interpretación integradora del contrato, fundada en la buena fe. Este principio constituye un elemento de gran importancia en la definición del ámbito de riesgos de cada uno de los contratantes según la convención. Y esto es así porque permite incorporar a dicha esfera una serie de contingencias que en atención a su sentido y finalidad ${ }^{120}$ deben pertenecer a la misma, aun cuando su asunción por el deudor no se desprenda expresamente de las declaraciones del

${ }^{119}$ Abeliuk Manasevich, René, cit. (n. 17), p. 104.

${ }^{120}$ Así lo sostiene LARENZ, Karl, cit. (n. 111), p. 118. El autor afirma: "La buena fe exige de cada uno de los contratantes el considerar como declarado por ambos y vigente como contenido del contrato y, por tanto, como conforme a su sentido, y como pactado objetivamente, de igual forma que si resultase exigido en el contrato mismo, todo aquello derivado no sólo de su tenor literal, sino de la finalidad objetiva reconocible del contrato, de la conexión con su sentido y de su idea fundamental; atendiendo, en el caso concreto, a los usos del tráfico y a los intereses de los contratantes". Estas ideas explican claramente la función desempeñada por la buena fe en la determinación del contenido del contrato, lo que evidentemente influye en la tarea de establecer la distribución de riesgos hecha por las partes en el mismo. 
contrato $^{121}$. Por ello se puede afirmar que el ámbito de riesgos de éstas se obtiene efectuando una interpretación del contrato en toda su plenitud ${ }^{122}$. Éste, desarrollado en base al principio de buena fe, refleja el margen dentro del cual cada parte asume los impedimentos que pueden afectar su cumplimiento. Dicho en otros términos: la interpretación integradora, unida a la meramente declarativa del contrato permite establecer cuáles riesgos asume cada una de las partes y cuáles no ${ }^{123}$.

d) Interpretación integradora del contrato y definición de un riesgo típico del deudor. Pues bien, corresponde ahora aclarar cuáles son en concreto los riesgos que en razón de la interpretación integradora del contrato quedan de cargo de cada parte según la convención. Para determinarlos, la primera idea a considerar es el conocimiento que todo contratante tiene o debe tener, al momento del nacimiento del vínculo contractual, de los medios y recursos, tanto materiales como personales, que deberá emplear para la ejecución de su respectiva prestación, pues ello debe reflejarse en la distribución de riesgos realizada en el contrato ${ }^{124}$. El deudor, según sea su actividad u organización, y teniendo en cuenta la naturaleza del contrato celebrado, debe ser capaz de anticipar las contingencias o riesgos que al interior de aquella pueden presentarse afectando su ejecución ${ }^{125}$. Tomando en cuenta ese conocimiento real o presunto, y con

${ }^{121}$ En relación con la distribución de riesgos hecha en el propio contrato, cabe tener en consideración que incluso Pothier, al referirse a la extensión de la indemnización, alude a la posibilidad de que el deudor se haya hecho cargo tácita o expresamente de ciertos daños y así aparezca del contrato, calificándolo como "riesgo del perjuicio". POTHIER, Robert Joseph, Tratado de las obligaciones (trad. cast. Buenos Aires, 1993), p. 93. Si bien no se trata de una afirmación vinculada directamente con la eventualidad del incumplimiento, el principio que subyace a la misma es perfectamente válido para éste.

${ }^{122}$ Cabe tener en cuenta en relación con esta idea, lo señalado por Alpa, quien en relación con la labor de interpretación contractual correspondiente al juez, destaca la necesidad de considerar el contrato como un todo, afirmando que la labor interpretativa debe estar encaminada a establecer la economía del contrato, lo que se consigue sobre la base de las declaraciones de las partes y de todas las circunstancias anteriores, concomitantes y sucesivas al acuerdo. Alpa, Guido - Bessone, Mario - Roppo, Enzo, Rischio contrattuale e autonomia privata, cit. (n. 106), p. 321.

${ }^{123}$ Estos últimos, por quedar fuera del aludido ámbito, cumplen con el primer requisito para constituir un caso fortuito: son ajenos al deudor.

${ }^{124} \mathrm{Al}$ contratar, las partes deben tener presente la realidad de cada una, pues ésta influirá en la ejecución de sus prestaciones, debiendo distribuir el riesgo en consideración a lo que saben es parte de aquella y que necesariamente deben controlar.

${ }^{125}$ En este sentido, Del Olmo afirma que para saber si un evento entra o no en la esfera de control del deudor, hay que acudir en primer lugar, a las previsiones del contrato en materia de distribución de riesgo, y en segundo lugar, a la esfera concreta 
base en la buena fe, pueden considerarse asumidos por el deudor aquellos riesgos originados en la actividad que debe desarrollar para cumplir, de modo tal que el acreedor puede a su vez contar con que, de verificarse un riesgo que corresponda a dicho ámbito, el deudor lo controlará -impidiendo que afecte el cumplimiento-y de no ser así, le indemnizará el daño derivado del incumplimiento. En este sentido, adquiere relevancia la buena fe, que actúa generando y protegiendo la confianza del acreedor en el control de dichos riesgos por parte del deudor.

El conocimiento que el deudor debe tener de sus medios y recursos es lo que explica que al contratar asuma el control de todo lo acontecido en ese contexto y que pueda afectar el cumplimiento, de modo tal que así lo entiende también el acreedor. No es necesario para ello un acuerdo expreso pues, como he señalado, la buena fe impone considerar como parte de los riesgos del deudor aquello que es usual en el tráfico, e indudablemente, los diversos intervinientes de éste parten de la base de que todo deudor pondrá en marcha ciertos medios que maneja y conoce y que es, por lo tanto, consciente del riesgo de incumplimiento que involucra la prestación que ha comprometido, según la actividad que deba desarrollar para llevarla a cabo. Importante función cumplen en este sentido el objeto y finalidad del contrato, así como la calidad del deudor ${ }^{126}$. Tales factores configuran una determinada gama de riesgos de la que aquel responde en virtud del contrato.

Es decir, la interpretación integradora del contrato pone en evidencia la existencia de un riesgo típico o característico que todo contrato impone al deudor ${ }^{127}$. Su determinación supone considerar la naturaleza de la relación contractual y de la prestación debida, así como las características del deudor y de los medios que empleará, o debiera emplear o poner en práctica para cumplir. Es un riesgo que corresponde a las operaciones realizadas y a los medios empleados por el deudor para ejecutar la prestación ${ }^{128}$. Como expresa un autor, por típico se entiende todo cuanto entra en la amplia categoría de aquello que, según la naturaleza de la actividad

de organización del deudor atendiendo al contenido y naturaleza de la relación obligatoria. Del Olmo Guarido, Natalia, cit. (n. 33), p. 202.

${ }^{126}$ Como expresa Bessone, los riesgos con que se carga a un empresario no son los mismos que corresponden a un operador ocasional. Bessone, Mario, Adempimento e rischio contrattuale, cit. (n. 90), p. 345.

${ }^{127}$ Pantaleón habla de un riesgo "implícitamente asumido al contratar". PANTALEÓN, Fernando, El sistema de responsabilidad contractual, cit. (n. 65), p. 1069. Si bien el autor lo califica como un criterio autónomo de responsabilidad contractual, de sus restantes afirmaciones se puede concluir que en definitiva con esa idea se refiere al riesgo típico del deudor, que por esa misma razón, se incorpora al contrato.

${ }^{128}$ Anelui, Franco, cit. (n. 8), p. 161. 
desarrollada, el deudor hace, predispone y organiza para cumplir ${ }^{129}$, a lo que debe agregarse aquello que debiese hacer, predisponer u organizar según los usos del rubro de que se trate.

Se trata entonces de una noción elástica ${ }^{130}$ o flexible, una categoría de extensión variable, que comprende en general todo aquello que, por la propia actividad del deudor, se entiende típicamente bajo su control en la ejecución de su prestación, y por lo mismo, constituye el contenido mínimo del ámbito de riesgos que el contrato pone de su cargo ${ }^{131}$. La labor del intérprete consistirá en definir o concretar en cada caso ese riesgo típico del deudor que, salvo una estipulación expresa del contrato ${ }^{132}$, le corresponde en razón de la interpretación integradora del mismo.

Por último, es necesario hacer presente que esta idea de asunción por el deudor de un riesgo típico, conformado por aquello considerado controlable por él al integrar su actividad de cumplimiento, es plenamente concordante con la forma en que, desde la perspectiva del análisis económico del derecho, se explica la responsabilidad del deudor. En efecto, a partir de la idea general de reducir los costos derivados del incumplimiento, esta doctrina afirma que la función del derecho de contratos es asignar el riesgo del incumplimiento - y consecuentemente, la responsabilidad-a aquel de los contratantes que se encuentre en una mejor posición para controlar o administrar dicho riesgo a un menor $\operatorname{costo}^{133}$. Dicha parte será quien pueda

\section{${ }^{129}$ Ibíd, p. 165}

${ }^{130}$ Así la califican Realmonte, Franceso, Caso fortuito e forza Maggiore, en Jus (Milano, 1987) 3, p. 272; CASTRONOvo, C., Tra rischio e caso fortuito. La responsabilità da cassette di sicurezza, en BBTC. 1 (1978), p. 57. Este último, destacando la idea de tipicidad, explica que el tipo individualiza el conjunto de características de una actividad o de una categoría formal.

${ }^{131} \mathrm{La}$ idea de que el deudor debe cargar con los riesgos controlables por él, es un principio arraigado en el Derecho anglosajón. Así lo reconoce FARNSWORTH, E. Allan, cit. (n. 92), p. 718, quien afirma que es un principio general que las partes deben ser responsables de los riesgos que están dentro de su control.

${ }^{132}$ Es claro que al ser el acuerdo de las partes la fuente de la distribución de riesgos, sus pactos expresos deben prevalecer por encima de aquello que se concluya como riesgo típico del deudor según los criterios señalados, de modo tal que es posible que en un caso concreto el deudor haya asumido un riesgo mayor o menor a ese riesgo típico. En este sentido, resulta pertinente lo sostenido por Stoll al pronunciarse sobre la regla del artículo 79 de la $\mathrm{CV}$, destacando que la voluntad de las partes puede ampliar o restringir el límite contenido en dicha norma, siendo la controlabilidad del riesgo sólo un indicio de la responsabilidad asumida por el deudor. STOLL, Hans, cit. (n. 21), par. 7.

${ }^{133}$ En este sentido: Torres López, Juan, cit. (n. 92), p. 58; Posner, Richard, cit. (n. 97), pp. 102, 118, 124; SCHÄFER, Hans-Bernd - OTT, Claus, cit. (n. 105), p. 262, quienes afirman que debe asumir el riesgo quien pueda evitarlo, asegurarlo o 
evitar o prevenir el incumplimiento tomando las medidas adecuadas para impedir que el riesgo se concrete, o bien, la que -aunque no sea capaz de impedirlo- pueda asegurarse contra el acaecimiento de dicho riesgo a un costo más bajo ${ }^{134}$.

Pues bien, comúnmente será el deudor quien, desde esta perspectiva, se encuentra en una mejor posición para administrar aquellos riesgos de incumplimiento que se presenten en su actividad de planificación y ejecución de la obligación, a la que el acreedor es ajeno, pudiendo por lo tanto adoptar y hacer uso de los mecanismos idóneos para impedir que el riesgo de incumplimiento se concrete ${ }^{135}$. Asimismo, el deudor es quien a más bajo costo podrá contratar los seguros que sean necesarios para enfrentar una eventual concreción de dicho riesgo ${ }^{136}$, asumiéndolo por consiguiente.

De esta forma, se puede apreciar que desde el punto de vista estrictamente económico, aparece también plenamente justificada la idea de poner de cargo del deudor los riesgos surgidos en su actividad de ejecución, pues en relación con dicha actividad, se encuentra en una condición de control de la que el acreedor carece.

e) Un supuesto relevante: el riesgo típico del deudor empresario. Su contenido. Según se ha visto, la interpretación integradora del contrato permite determinar el riesgo típico asumido por cada deudor. En relación con ello, es claro que los supuestos que más interés revisten son aquellos en que el deudor contrae su obligación en calidad de empresario. Es evidente que el engranaje que implica una empresa y su organización da lugar al surgimiento de diversos eventos susceptibles de

soportarlo a un menor costo; FERRARINI, Guido, Il controllo del rischi come criterio di responsabilità nella vendita internazionale, en QGC. 39 (1981), p. 374.

${ }^{134}$ SCHÄFER, Hans-Bernd - ОTт, Claus, cit. (n. 105), pp. 266 ss. explican que si el riesgo es asegurable, debe soportarlo la parte -denominada "cheapest insurer"- que pueda contratar un seguro con la prima más barata. En tanto, cuando se trate de un riesgo que no sea susceptible de aseguramiento, es necesario hacer recaer el mismo sobre aquella parte que pueda soportar mejor el riesgo, a la que llaman superior "risk bearer".

${ }^{135}$ En este sentido se expresa FerRARINI, Guido, cit. (n. 133), p. 374, quien afirma que generalmente el deudor es quien mejor puede prevenir el riesgo porque conoce la condiciones de ejercicio de su empresa y control a los factores empleados para la ejecución del contrato. La misma idea se aprecia en Trimarchi, quien afirma que es frecuente que el deudor, antes que el acreedor, esté en situación de poder adoptar las medidas idóneas para prevenir el daño. Trimarchi, Pietro, Sul significato economico, cit. (n. 56), p. 522.

${ }^{136}$ Así por ejemplo, tratándose del hospedero, Trimarchi señala que es más práctico que sea éste y no el viajero quien contrate un seguro contra el riesgo de hurto del equipaje pues se encuentra en mejor grado de asegurarse contra dicho daño. TrimarChI, cit. (n. 56), p. 517. 
afectar la ejecución de la prestación, los que a través de la interpretación del contrato deben quedar de cargo del deudor. Además, si se tiene en cuenta la realidad del tráfico, puede apreciarse que en gran cantidad de relaciones contractuales, incluso las más cotidianas, al menos una de las partes tiene características de empresa. Así ocurre, por ejemplo, si una persona encarga a un taller mecánico la reparación de su automóvil: la organización del taller comúnmente supondrá la puesta en marcha de un conjunto de recursos destinados a cumplir con las obligaciones contraídas con los clientes. Lo mismo acontece cuando se solicitan los servicios de un banquetero para organizar una fiesta. El cumplimiento del contrato implicará para este último el despliegue de un grupo más o menos complejo de medios que debe conocer y manejar pues forman parte de su giro o actividad habitual. Así se advierte también por ejemplo cuando se contrata para la remodelación de un inmueble: el contratista debe disponer personas y medios materiales e inmateriales los que, organizados adecuadamente, forman parte de la actividad que compromete para satisfacer el interés de quien ha encargado la obra. Una situación similar puede observase en situaciones tan habituales como aquellas en que se contratan servicios de mantención de un jardín; de limpieza de una piscina, o el transporte de determinados bienes de un lugar a otro, etc. Son innumerables los supuestos en que se celebran contratos en los que el deudor funciona como empresa, con toda la estructura organizacional que ésta supone. Esta es la razón por la que la definición del riesgo típico de un empresario es de especial relevancia práctica ${ }^{137}$.

El contenido de este riesgo típico puede ser dividido en dos grandes categorías. Por una parte, se encuentran los riesgos vinculados con los sujetos que participan de la actividad de empresa, es decir, las personas cuya intervención es necesaria para el desarrollo de la misma. Y por otra parte, se ubican los riesgos vinculados con los medios no personales empleados en la actividad empresarial, es decir, los correspondientes a todos los recursos materiales e inmateriales utilizados por el empresario en la organización, preparación y ejecución de sus prestaciones.

i) En primer lugar se presenta la categoría de los riesgos vinculados con los sujetos que intervienen en la actividad del empresario.

${ }^{137}$ En este sentido, Montes Penadés destaca que en la actualidad el tráfico económico se encuentra basado en la organización de la empresa, como unidad de producción y como colectivo de personas, así como organización de medios de muy diversa índole para la producción y el intercambio de bienes y servicios. MonTes Penadés, Vicente, cit. (n. 112), p. 208. Por su parte, Anelli expresa que actualmente la idea de empresa se presta a identificar la esfera de lo que el obligado realiza y coordina bajo su dirección y responsabilidad para cumplir, ANELLI, Franco, cit. (n. 8), p. 171. 
En esta categoría cabe ubicar, en general, el riesgo de incumplimiento derivado de la conducta de todas aquellas personas, naturales o jurídicas, distintas del sujeto empresario y que intervienen, ya sea en la planificación, preparación o ejecución de su prestación, contribuyendo en alguna medida al cumplimiento ${ }^{138}$.

El funcionamiento de una empresa supone, por su propia definición, la participación de un cierto número de personas que conforman el factor trabajo dentro de la misma, desarrollando a su interior funciones que inciden directa o indirectamente en el cumplimiento de la prestación a satisfacción del acreedor. Al mismo tiempo, los avances tecnológicos, así como las exigencias económicas, han favorecido el fenómeno de la especialización, de modo tal que muy habitualmente el empresario deberá recurrir a terceros que de diversa forma participan en la ejecución de sus prestaciones o constituyen el presupuesto del cumplimiento de las mismas. Así ocurre con los denominados subcontratistas o personas que sustituyen en alguna medida al deudor en la ejecución; también es el caso de los proveedores, quienes si bien no participan directamente de la ejecución, influyen igualmente en ella con los suministros de que se trate. De ahí entonces que exista una pluralidad de sujetos cuya actividad, junto con ser necesaria para el desarrollo de la empresa, constituye un riesgo de la misma.

Conforme a lo señalado, dentro de esta categoría de riesgos debe ubicarse en primer lugar la actividad de los denominados auxiliares del deudor. En una acepción amplia, esta expresión comprende a "todos aquellos que se emplean en el cumplimiento de la prestación prometida por el deudor" ${ }^{139}$, o a "todas las personas de que se sirve para la ejecución

${ }^{138}$ En este sentido, cabe destacar lo señalado por Claro Solar, quien afirma que "la responsabilidad del deudor por los actos u omisiones de sus auxiliares es una imperiosa necesidad económica", impuesta por el desarrollo de la industria, y que "en la organización económica contemporánea una multitud de individuos coopera de diversas maneras a la ejecución de una obra”. Claro Solar, Luis, cit. (n. 14), p. 543. En similares términos, Fuenzalida expresa que "La complejidad de la vida moderna determina que, en la gran mayoría de los casos, el deudor no cumpla directamente su obligación, sino que por medio de "ayudantes" y "sustitutos" (lo destacado es del autor), FuenZALIDA, Sergio, Los terceros en la responsabilidad contractual, en RDJ. 57 (1960), primera parte, p. 114.

${ }^{139}$ Torralba, Orencio, cit. (n. 86), p. 1156. A propósito de esta definición amplia de auxiliar, cabe destacar que por lo mismo es aplicable a toda clase de deudores, de modo tal que su conducta no es un riesgo que competa exclusivamente al deudor empresario. Por el contrario, ella es susceptible de integrar el riesgo típico de cualquier deudor que recurra a la intervención de terceros para el cumplimiento de su prestación. En tal sentido, Roppo afirma de manera general que la responsabilidad por los auxiliares es un riesgo que debe asumir el deudor. Roppo, Enzo, Il contratto, cit. (n. 94), p. 257. Y también de modo general Castilla Barea afirma: "El deudor 
de su obligación"140. Requisitos generales para poder dar la calificación de auxiliar a una determinada persona son: que se trate de sujetos cuya intervención en la ejecución sea promovida por el deudor, y que su actuación sea completamente ajena al acreedor ${ }^{141}$. Ahora bien, a pesar de estas exigencias, que en alguna medida ya delimitan el concepto, en doctrina suele hacerse una distinción que permite restringir la noción de auxiliar según cual sea la relación concreta entre ese sujeto y el deudor, así como en atención a cual sea la forma en que aquel interviene en la labor de ejecución. Ello permite distinguir ${ }^{142}$, por una parte, los auxiliares en sentido estricto, también denominados ayudantes; y por otra, los llamados sustitutos del deudor ${ }^{143}$.

Los llamados auxiliares en sentido estricto o ayudantes, se caracterizan porque desempeñan sus funciones en una relación de dependencia respecto del deudor o, mejor dicho, dentro de la organización de éste último y bajo su supervisión. En este sentido, es necesario destacar que lo determinante para su calificación como tales es su sujeción a las instrucciones del deudor: el desarrollo de sus labores se verifica estrictamente de acuerdo a las indicaciones y reglas fijadas por el propio empresario, y por consiguiente, su participación se traduce en prestarle colaboración ${ }^{144}$ en las tareas de preparación o ejecución de la prestación. Ahora bien, la calidad de auxiliares en sentido estricto no es consecuencia necesariamente de la existencia de un contrato de trabajo entre el deudor empresario y quien le colabora, aun cuando la mayor parte de las veces es así, lo que

de una obligación contractual es responsable del incumplimiento producido por los dependientes o auxiliares a quienes encomiende la realización de la prestación debida aunque no exista en nuestro Código Civil una norma que, de modo general, establezca la responsabilidad contractual por actos de tales dependientes". CASTILLA BAREA, Margarita, Comentario a la STS de 14 de marzo de 2001, en CCJC. 58 (2002), p. 63.

${ }^{140}$ Claro Solar, Luis, cit. (n. 14), p. 546.

${ }^{141}$ Así se sostiene comúnmente por la doctrina. Por todos, véase Torralba, Orencio, cit. (n. 86).

${ }^{142}$ Cabe destacar, en todo caso, que se trata de una distinción cuya relevancia se reduce exclusivamente al plano conceptual, pero que no incide en la determinación del riesgo típico del empresario, pues indudablemente ambas categorías forman parte del mismo.

${ }^{143}$ Recogen esta distinción, entre otros, Torralba, Orencio, cit. (n. 86), pp. 1158 ss.; Moreno Quesada, Bernardo, Problemática de las obligaciones de hacer, en RDPr. (1976), p. 492; FuENZALIDA, Sergio, cit. (n. 138), p. 112.

${ }^{144}$ Según Fuenzalida, Ibid, lo que define a los ayudantes es que sólo colaboran con el deudor en el cumplimiento de la obligación. Moreno Quesada afirma que "el ayudante es el que colabora o coopera con el deudor en el cumplimiento de su obligación”. MOREno Quesada, Bernardo, ibid. 
permite de inmediato calificar al trabajador como auxiliar o ayudante del empresario ${ }^{145}$. Lo anterior, porque también puede ubicarse en esta categoría a todas aquellas personas pertenecientes a una empresa que el deudor ha contratado para que le proporcione personal que se incorporará regularmente a su organización y cumplirá funciones de colaboración en la labor de preparación y cumplimiento de sus obligaciones ${ }^{146}$.

De acuerdo a lo señalado, cabe calificar como auxiliar en sentido estricto o ayudante, al técnico que trabaja para una empresa de reparación de computadores cuya función consiste en reinstalar los programas afectados por las tareas de ajuste del equipo, desarrolladas previamente por otro trabajador de la misma; y asimismo, pertenece a dicha categoría el guardia de un banco que contrató a la empresa de seguridad de la que aquel es dependiente para que le proporcione personal especializado en esas labores. Si bien el guardia no es un trabajador de la empresa bancaria sino de la de seguridad, colabora con el cumplimiento de las obligaciones contraídas por aquella respecto de sus clientes, y lo hace dentro de su organización y sometido a sus reglas de funcionamiento.

Por su parte, los llamados sustitutos son aquellas personas a las que el deudor encarga en todo o parte la ejecución de la obligación. Éstos se caracterizan porque desarrollan su actividad de manera autónoma y no simplemente colaborando con aquel ${ }^{147}$, sino en definitiva remplazándolo. No se trata de simples colaboradores porque no desempeñan sus funciones

${ }^{145}$ En relación con el personal del empresario, cabe adelantar que sólo integran la categoría de los auxiliares quienes efectivamente tienen participación e influencia en la ejecución de la obligación, quedando fuera de la misma aquellos trabajadores cuyas funciones no inciden de manera inmediata en el desarrollo de la prestación -básicamente, quienes realizan labores administrativas- sin perjuicio de que su actividad igualmente forma parte del riesgo que pesa sobre el empresario, como se verá luego.

${ }^{146}$ Me refiero al fenómeno conocido como externalización o "outsourcing”, en aquella modalidad en que una empresa recurre a otra para que le provea determinados trabajadores que prestan sus servicios dentro de las dependencias y bajo el control de la primera. En rigor, se trata de una forma de subcontratación, pero que no supone encargar a un tercero el cumplimiento independiente de una parte determinada de la obligación del deudor, sino que tiene por objeto que el personal de otra empresa colabore en la propia de manera regular. De ahí que aquellas personas que desempeñan funciones en razón de un contrato de esta naturaleza deban calificarse como auxiliares del deudor en sentido estricto.

${ }^{147}$ Torralba destaca precisamente que la ausencia de colaboración es lo que los diferencia de los ayudantes. Torralba, Orencio, cit. (n. 86), pp. 1158. Moreno Quesada define al sustituto como "una persona independiente que el deudor encarga de ejecutar todo o parte de la prestación”. MORENO QUESADA, Bernardo, cit. (n. 143), p. 492. En la expresión "independiente" que emplea el autor, se manifiesta la idea de ausencia de colaboración que caracteriza al sustituto y lo distingue del ayudante. 
asistiendo al deudor, sino que se ubican en lugar de éste en relación a la actividad de cumplimiento, sea total o parcialmente ${ }^{148}$. En esta categoría se ubican comúnmente los subcontratistas ${ }^{149}$, es decir, personas o empresas que, de manera independiente, se hacen cargo de una específica parte de la compleja labor de cumplimiento de una prestación. Es el caso, por ejemplo, del transportista con quien el deudor -una empresa fabricante de muebles que ha comprometido con su cliente la confección e instalación del mobiliario de una cocina- contrata el servicio de traslado de los bienes al domicilio del acreedor; o el de la empresa a la que un productor de vino encarga la fabricación e instalación de las etiquetas de sus botellas para proceder a la entrega de las mismas a su comprador ${ }^{150}$.

En segundo lugar, junto con los auxiliares en sentido estricto y los sustitutos, también aparecen como sujetos involucrados en la actividad de cumplimiento del empresario los proveedores del mismo: aquellos que suministran a su empresa los insumos o materias empleadas en el desarrollo de la actividad de ejecución, por ejemplo, el productor de harina que provee a una empresa de pastelería. Si bien no se puede afirmar que los proveedores colaboran o intervienen en la ejecución propiamente tal -por lo que no entran en la categoría de auxiliares en sentido amplio- sí cabe calificar su función como un presupuesto del oportuno y correcto cumplimiento por parte del empresario que recurre a ellos. En efecto, una falta de suministro puede dar lugar a una infracción del deber prestacional

${ }^{148}$ En relación con esto, cabe poner énfasis, como lo hace Torralba, en que se trata de una sustitución exclusivamente material, limitada a la actividad de cumplimiento, y en ningún caso jurídica, en tanto el deudor es el único obligado frente al acreedor. Torralba, Orencio, cit. (n. 86), pp. 1160.

${ }^{149}$ Debe tratarse, como es lógico, de subcontratos cuyo objeto no sea proporcionar personal al deudor, pues en tal caso, según lo señalado precedentemente, nos ubicamos en la categoría de los auxiliares en sentido estricto y no de simples sustitutos.

${ }^{150}$ En el Derecho uniforme, y más precisamente en la CV., la noción de auxiliares es estricta, lo que se traduce en que los terceros encargados en todo o parte de la ejecución de la prestación no se consideren como tales. Ello tiene gran trascendencia en dicho cuerpo normativo, pues la disposición del artículo 79, 2, establece para ellos un régimen especial que los excluye de la esfera de control del deudor, asignándole directamente responsabilidad a éste por los incumplimientos que provengan de un tercero encargado, aunque contemplando la posibilidad de que este último acredite que se ha configurado respecto de él la causa de exoneración del artículo 79 (1), lo que puede conducir a su vez a la exención del propio deudor. Se trata de un régimen bastante particular, que sin embargo no ha sido seguido por los PECL ni por los Principios de Unidroit, que no establecen reglas especiales sobre el particular, de modo que en ellos la actividad de los terceros encargados queda sujeta a las reglas generales y perfectamente puede considerarse parte del riesgo típico del deudor. 
de este último, con la consecuente lesión del interés de su acreedor. De ahí entonces que su participación integre el riesgo típico de la empresa.

Por último, también se debe incluir dentro de esta categoría de riesgos correspondientes a los sujetos involucrados en la actividad empresarial, al personal administrativo de la empresa: secretarias, mensajeros, encargados del aseo, telefonistas, etc. Si bien éstos no pertenecen a la categoría de auxiliares en el cumplimiento - pues no colaboran directa o materialmente en la tarea de preparar y llevar a cabo el cumplimiento de las obligaciones contraídas por la empresa- igualmente forman parte de la organización del deudor. Es innegable que el desempeño de sus labores es fundamental para el adecuado funcionamiento de la empresa, y consecuentemente, para que pueda darse fiel cumplimiento a las diversas obligaciones contraídas por el empresario. Es perfectamente posible que la inejecución de una obligación tenga su origen en la conducta de alguno de esos trabajadores, lo que indudablemente es una circunstancia con la que debe contar el empresario al contratar.

Lo expresado en los apartados anteriores permite concluir que la actividad de todos los sujetos mencionados pertenece al riesgo típico de una empresa. La necesidad de intervención de los mismos claramente es una circunstancia conocida por todo empresario que contrae una obligación: éste sabe desde la celebración del contrato que deberá recurrir a otras personas o empresas para la ejecución de su prestación, y por lo tanto, desde ya es consciente, o debe serlo, del riesgo de que un incumplimiento pueda originarse en la actuación de alguno de ellos, sea por la acción de sus trabajadores ${ }^{151}$, porque la conducta desplegada por el encargado no se

${ }^{151}$ Por ejemplo, la incorrecta manipulación de una materia que torna defectuoso el producto final; un daño provocado en un objeto que se encontraba en dependencias de la empresa para su reparación, etc. Asimismo, cabe aludir a un supuesto en que habitualmente la acción de sus trabajadores determina el incumplimiento de una obligación por parte del empresario: la huelga. Es objeto recurrente de discusión el determinar si ella puede o no constituir una causa de exoneración del empresario. Desde la perspectiva planteada en estas líneas, prima facie podría afirmarse que, por tratarse de un hecho que se vincula directamente con el desarrollo de la actividad de la empresa y por tener su origen inmediato en un elemento de la misma, como son los trabajadores, la huelga se incorpora dentro de los riesgos que el empresario asume por el contrato, por formar parte de su riesgo típico, de modo tal que no cabe exoneración de su parte por no ser un hecho externo a él. Sin embargo, tal afirmación puede resultar desmentida por el contenido concreto del contrato en que incide la huelga, pues éste puede impedir incorporar, por vía de interpretación, determinados conflictos laborales con que el empresario no debía contar como riesgo de su cargo, y por lo tanto, tampoco el acreedor podía esperar de su parte el control de los mismos. Así puede ocurrir con las huelgas ilegales surgidas en empresas sin antecedentes de ese tipo, o aquellas que son consecuencia de movilizaciones generales de trabaja- 
ajusta a lo pactado con el acreedor, o simplemente, porque el proveedor seleccionado falla en el suministro comprometido. El empresario conoce la actividad que desarrolla y sabe o debe saber que en el desenvolvimiento de la misma se pueden presentar dichas contingencias. Por lo mismo, a su vez el acreedor confía en que el deudor ha tenido en cuenta ese riesgo, que lo ha tomado en consideración al celebrar el contrato y espera por lo tanto que lo controle ${ }^{152}$, evitando que se concrete, y de no ser así, que asuma las consecuencias dañosas del incumplimiento. Por esta razón, si en el contrato no se ha estipulado nada en contra ${ }^{153}$, puede concluirse que, por pertenecer al riesgo típico de su actividad, las partes lo han puesto de cargo del deudor, quedando incorporado en su ámbito de riesgos, y así se desprenderá de la interpretación integradora del contrato ${ }^{154}$. Por ello, si el

dores que no existían al momento de la celebración del contrato. Una regla válida de manera absoluta es muy difícil de establecer. Lo claro es que en definitiva debe prevalecer el contenido del contrato que, interpretado en los términos expresados anteriormente, debe ser la fuente de la solución en cada caso concreto. En España, Díez-Picazo afirma que en estos casos lo determinante es establecer en qué medida la huelga puede ser colocada dentro de la esfera de control y de planificación del deudor. Díez-Picazo, Luis, Fundamentos, cit. (n. 65), p. 733. Por su parte, Carrasco Perera afirma que la huelga es un suceso interno a la actividad de la empresa, pero que sin embargo, no siempre hay que rechazar su eficacia exoneratoria. CARRASCO Perera, Ángel Francisco, Artículo 1105, cit. (n. 28), p. 41. Si bien el autor no profundiza en las razones de esto último, su expresión sirve para explicar la idea de que aunque a priori cabe cargar al empresario con el riesgo de la huelga porque espacial y funcionalmente se integra en su organización, ello no es suficiente. Lo relevante, repito, es el contrato.

${ }^{152}$ En relación al control concreto que el empresario puede ejercer sobre la actividad de los sujetos involucrados, cabe tener presente que será distinto según de quien se trate. En efecto, sólo respecto de los auxiliares en sentido estricto y de su personal administrativo ostenta una autoridad y poder de fiscalización efectivo y constante. Tratándose en cambio de los encargados y los proveedores, el control se traduce en la facultad de elección que el deudor tiene respecto de los mismos. Esto último es destacado en relación a los proveedores por PANTALEÓn, Fernando, El sistema de responsabilidad contractual, cit. (n. 65), p. 1070.

${ }^{153}$ Por ejemplo, un pacto en que se disponga que el incumplimiento originado en la conducta de un determinado subcontratista no será de cargo del deudor empresario.

${ }^{154}$ En relación con la asunción de este riesgo por el deudor a través del propio contrato, cabe tener en cuenta lo señalado, en relación a los auxiliares, por DíezPicazo, cuando afirma que "normalmente la actividad de los auxiliares y dependientes del deudor se encuentra comprometida por éste según la naturaleza misma de la prestación. Por consiguiente, se encuentra implícita en la voluntad contractual”. Esa incorporación implícita a que alude el autor, cuadra perfectamente con la idea de que la interpretación del contrato permite concluir que se trata de un riesgo que las partes han acordado poner de cargo del deudor. Y ello queda bastante claro con el ejemplo 
riesgo proveniente de la intervención de alguno de estos sujetos en definitiva se verifica, produciéndose un incumplimiento que tiene su origen en su actuación, el deudor no podrá alegar su exención de responsabilidad. Ello, porque no se trata de un riesgo ajeno a él ${ }^{155}$ conforme al contrato, y por lo tanto, no puede configurar un caso fortuito a su respecto ${ }^{156}$.

En nuestro derecho es posible encontrar sustento para este planteamiento. Ello, a pesar de la ausencia en el Código Civil de una regla de carácter general que establezca la responsabilidad del deudor por los incumplimientos originados en la actividad de las personas involucradas en la ejecución de su obligación. En efecto, la norma del artículo 1679 CC. -que dispone que en el hecho o culpa del deudor se comprende el hecho o la culpa de las personas por quienes fuere responsable ${ }^{157}-$ así como una

que a continuación entrega, consistente en la solicitud de reparación de un vehículo a un taller mecánico, en que las partes convienen implícitamente que será reparado por los operarios del taller. Dí́z-PiCAzo, Luis, Fundamentos, cit. (n. 65), p. 731. Por su parte, Betti señala que si el deudor interpone auxiliares, lo hace a su propio riesgo y peligro. BetTi, Emilio, Teoría General, cit. (n. 55), p. 168.

${ }^{155}$ Sobre este punto, Torralba afirma que, tratándose de la actividad de los auxiliares, no se está ante un acontecimiento externo al deudor, por constituir algo que ocurre en el seno de su organización. Torralba, Orencio, cit. (n. 86), p. 1.156.

${ }^{156}$ En España, Díez-Picazo, además de considerar -como he señalado anteriormente- que la actividad de los auxiliares integra el acuerdo de las partes, lo que justifica la responsabilidad del deudor por ellos, agrega, en relación con los proveedores, que el hecho de éstos debe considerarse siempre como parte de la esfera de control del deudor. Díez-Picazo, Luis, Fundamentos, cit. (n. 65), p. 732. A su vez, Pantaleón hace una distinción según se trate o no de proveedores monopolistas, afirmando que si no lo son, la regla es la incorporación de sus fallos en la esfera típica de control del deudor, y admitiendo, en cambio, la exoneración del deudor ante el fallo de un proveedor monopolista que era imprevisible al momento de contratar. PANTALEÓN, Fernando, El sistema de responsabilidad contractual, cit. (n. 65), p. 1.070. A mi juicio, la distinción planteada por este autor no puede aceptarse en términos tan absolutos, en tanto la calidad de monopolista del proveedor será lógicamente conocida por el deudor $-\mathrm{y}$ muy probablemente también por el acreedor- al contraer la obligación, lo que implica saber que una falla del mismo le hará incurrir en un incumplimiento, y si nada se expresa sobre el particular en el contrato - por ejemplo, una cláusula que le autorice la exoneración en determinados supuestos de falta de suministro- es posible interpretar el mismo poniendo de su cargo el riesgo de incumplimiento o cumplimiento defectuoso de ese proveedor, a pesar de su calidad de monopolista.

${ }^{157}$ Se trata de una norma ubicada en una sede concreta: pérdida de la cosa que se debe, pero que, como afirma Fuenzalida, Sergio, cit. (n. 138), p. 106, "contiene una regla general en materia de obligaciones", sean éstas de dar, hacer o no hacer. El mismo autor señala también como otra regla de carácter amplio en la materia, la del artículo 1590 inciso primero, que a propósito de la obligación de entrega de un cuerpo cierto, se pone en el caso de deterioros que provengan del hecho o culpa del deudor, o de las personas por quienes éste es responsable, coincidiendo con la redacción del artículo 1679. 
serie de disposiciones dispersas en la regulación particular de los contratos, que recogen la misma idea ${ }^{158}$, permiten sostener esta responsabilidad como una regla general aceptada por nuestro legislador. La disyuntiva que según los autores ${ }^{159}$ plantea el tema, es definir a quiénes se refiere el artículo 1679 CC. con la expresión genérica "personas por las que el deudor es responsable".

Las alternativas, según la doctrina, son tres. En primer lugar, entender comprendidas en esa categoría sólo a las personas aludidas en las normas particulares respectivas, con lo que la responsabilidad del deudor por terceros quedaría reducida a los casos expresamente previstos por la ley ${ }^{160}$. La segunda posibilidad sería aplicar por analogía la norma del artículo 2320

${ }^{158}$ Así ocurre en los artículos 1925, 1926, 1941, 2000, 2003 regla 3a , 2014, 2015, 2135, 2242, 2243 CC. Por ejemplo, en materia de arrendamiento de cosas, el artículo 1926 inciso primero establece que si el arrendador por hecho o culpa suya o de sus agentes o dependientes es constituido en mora de entregar, el arrendatario tendrá Derecho a indemnización de perjuicios, es decir, el arrendador es responsable por el incumplimiento en que se traduce la mora incluso cuando ello derive de la conducta de las personas mencionadas en la norma. Por su parte, el artículo 2015 CC., relativo al arrendamiento de transporte, establece en su inciso final que la responsabilidad del acarreador tiene lugar no sólo por su propio hecho, sino también por el de sus agentes o dependientes. A su vez, el artículo 2135 CC. en materia de mandato, establece la posibilidad de delegación por parte del mandatario y le hace responsable -bajo ciertos supuestos previstos por la norma- de los hechos del delegado, como de los suyos propios. Esta disposición tiene la particularidad de que se refiere en definitiva a un supuesto de subcontrato, y expresamente hace responsable al deudor de la actuación del subcontratista. Por otra parte, cabe destacar que en el Código de Comercio también se advierte este principio de responsabilidad del deudor por los terceros que involucre en el cumplimiento de su obligación. Así ocurre de hecho en el artículo 168 CCom., que en materia de contrato de transporte, recoge dicha idea, al disponer: "Aunque el transporte imponga la obligación de hacer, el que se obliga a conducir personas o mercaderías puede, bajo su responsabilidad, encargar la conducción a un tercero. En este caso el que primitivamente ha tomado sobre si la obligación de conducir, conserva su carácter de porteador respecto del cargador con quien ha tratado, y toma el carácter de cargador respecto del que efectivamente haga la conducción de las personas o mercaderías". Al respecto, se ha fallado recientemente que dicha norma deja en claro "que si bien el porteador primitivo está facultado para encargar a un tercero la conducción de las mercaderías que a el se le ha encomendado transportarlas, no queda exento de su responsabilidad, frente a quien contrató con él", sentencia de la Corte de Apelaciones de Valparaíso de 14 de abril de 2008, disponible en www. legalpublishing.cl, número identificador 38.830.

${ }^{159}$ Plantean la cuestión en estos términos: Abeliuk Manasevich, René, cit. (n. 17), p. 538; FuenZalida, Sergio, cit. (n. 138), p. 112.

${ }^{160}$ Esta es la opinión sostenida por Coustasse, Alberto - ITURRA, Fernando, cit. (n. 18), p. 94. 
CC., localizado en sede de responsabilidad aquiliana ${ }^{161}$. Y por último, como tercera alternativa, está la de interpretar las diversas normas que admiten dicha responsabilidad como manifestación de una regla general. Esta última opinión es la que prevalece en nuestra doctrina ${ }^{162} \mathrm{y}$ ha sido acogida también por nuestros tribunales ${ }^{163}$. Ello permite sostener en nuestro

${ }^{161}$ Por esta alternativa parece inclinarse Meza Barros cuando afirma que "La ley ha señalado, en el título de los delitos y cuasidelitos, quiénes son las personas por cuyos actos se es responsable”, Meza Barros, Ramón, cit. (n. 12), p. 448.

${ }^{162}$ Afirman como regla general la responsabilidad del deudor por los terceros que intervienen en el cumplimiento: Claro Solar, Luis, cit. (n. 14), p. 541; AbeliuK Manasevich, René, cit. (n. 17), p. 539, aunque este autor exige la culpa del tercero; Fuenzalida, Sergio, cit. (n. 138), p. 112; RodríGuez Grez, Pablo, cit. (n. 14), p. 197; Fueyo Laneri, Fernando, Derecho Civil, cit. (n. 13), p. 276; Alessandri, Arturo, Teoría de las Obligaciones (Santiago, 1930), p. 75; Larraín Ríos, Hernán, Teoria General de las Obligaciones (Santiago, 2002), p. 222; Gatica Pacheco, Sergio, Aspectos de la indemnización de perjuicios por incumplimiento de contrato (Santiago, 1959), pp. 64 ss.

${ }^{163}$ En efecto, así lo declaró la Corte de Apelaciones de Santiago. En el caso, el dueño de un automóvil celebra contrato con la dueña de un garage, para guardar su vehículo en uno de los "boxes" de propiedad de esta última. Vigente el contrato, el vehículo es sacado por un hijo de la mayordoma del garage, quien lo choca. El tribunal establece la responsabilidad de la dueña del garage fundado en que "en la culpa del deudor se comprende la de las personas por las que fuere responsable, de acuerdo con lo que dispone el artículo 1679, y entre éstas se hallan los dependientes, como se desprende de los artículos 1925, 1926, 2242, 2320 y 2322”. Sentencia de 30 junio 1943, en $R D J .40$ (1943), sec. 2a , p. 77. En una sentencia más reciente del mismo tribunal se reitera de manera aun más clara la idea de la responsabilidad del deudor por los terceros que incorpore en el cumplimiento de su prestación. Y lo hace en relación a los subcontratistas. Se trataba de una demanda presentada en contra de una agencia de turismo reclamando la indemnización de los daños sufridos por el contratante de un tour al accidentarse el bus en que viajaba, vehículo cuyo servicio había sido subcontratado por la agencia de viajes. El tribunal declara la responsabilidad contractual de la empresa demandada, afirmando: "Que, en consecuencia, encontrándose vinculadas las partes por un contrato en virtud del cual la demandada se obligó voluntariamente a prestar un servicio de la naturaleza antes indicada, cobra aplicación la norma del artículo 1679 CC., en virtud del cual 'En el hecho o culpa del deudor, se comprende el hecho o culpa de las personas por quienes fuere responsable'. Ello implica, como ha sostenido la doctrina, que la responsabilidad del deudor absorbe o comprende, sin excepción, el hecho o culpa de la persona de quien se es responsable y por ende, el hecho o culpa del tercero debe considerarse como el hecho o culpa del deudor. En la especie, esto significa que la Agencia de Viajes debe responder del hecho o culpa de quienes conducían el bus en que la demandante viajaba al momento de producirse el accidente, careciendo de relevancia que hubieren sido sus propios dependientes o personas que haya contratado para el cumplimiento de tales fines, pues en definitiva la prestación del servicio es de cargo de la empresa que se obligó a otorgarlo y debe responder de cualquier circunstancia, comprendida dentro del ámbito de las actividades relacionadas 
derecho la responsabilidad del deudor en todos los supuestos de intervención de terceras personas en las actividades destinadas a preparar y ejecutar su prestación ${ }^{164}$. Esta responsabilidad puede perfectamente fundarse en la aceptación, por parte de nuestro legislador, de la idea del contrato como un mecanismo de distribución del riesgo del incumplimiento, el que de-

con el viaje contratado, que cause daño a sus usuarios o que entorpezca, o impida el cabal cumplimiento de la obligación contraida" (lo destacado es mío). Sentencia de la Corte de Apelaciones de Santiago de 4 de julio de 2008, disponible en www.legalpublishing.cl, número identificador 39.305. Esta sentencia es especialmente relevante, porque además de afirmar como una regla de aplicación general la contenida en el artículo 1679 CC., al fundamentar la responsabilidad de la empresa demandada, expresa que ésta debe responder de todo aquello que se ubique dentro de la actividad a realizar para dar cumplimiento a su prestación. Aunque no lo diga explícitamente, con ello está aludiendo al riesgo típico derivado de la ejecución de la prestación. De ahí que no sea procedente la exoneración del deudor. La Corte Suprema también ha admitido en términos generales la responsabilidad del deudor por la intervención de terceros en la prestación. En particular, en un supuesto de demanda dirigida contra una clínica, con la cual había contratado el paciente, fundada en la actuación negligente de uno de sus médicos, declara: "El profesional médico actúa como un mero auxiliar del hospital o clínica privada y la responsabilidad que se está juzgando en el proceso es la del deudor, esto es, de este último y no la del médico, que es un tercero para los efectos de la relación contractual con el paciente [...] no cabe hablar de responsabilidad del hospital o la clinica por el hecho ajeno en sede contractual; la culpa o negligencia del médico, desde una perspectiva estrictamente jurídica, es la culpa o negligencia del hospital, único obligado contractualmente". Y en términos más generales expresa: "El deudor es responsable del incumplimiento ocasionado por sus auxiliares. Aunque encargara el cumplimiento de la obligación a un empleado suyo, responde en cuanto él era el obligado a cumplir, sólo le libera el caso fortuito y no puede considerarse que la intervención de éste lo sea". Sentencia Corte Suprema, 24 de Septiembre de 2007, rol No 4103-2005, disponible en www.puntolex.com.

${ }^{164}$ En todo caso, teniendo en cuenta la variedad de personas enunciadas en las disposiciones aludidas: dependientes, agentes, familiares, huéspedes, etc., no cabría en principio hablar simplemente de responsabilidad por los auxiliares, debido al significado preciso que, según he indicado, corresponde a dicha noción. Para ello, habría que decir que nuestro legislador acoge una noción bastante lata de dicha expresión, comprensiva tanto de quienes colaboran con el deudor en el cumplimiento, como de aquellos a los que éste encarga todo o parte del mismo, e incluso a quienes, como señala FuenZALidA, Sergio, cit. (n. 138), p. 113, el deudor llama para "hacerlos compartir en el goce de la cosa que debe restituir", como ocurre con los familiares y huéspedes en el caso del contrato de arrendamiento. Inclusive, en ciertos casos también alcanzaría a terceros extraños, cuya conducta nuestro legislador pone a veces de cargo del deudor, como ocurre en los artículos 2242 y 2243 CC., lo que se explica por la naturaleza del contrato, según se verá más adelante. Sin embargo, lo claro es que, más allá de la denominación que se les dé, lo que interesa es la indudable responsabilidad del deudor por la conducta de aquellas personas que involucra en el cumplimiento de su obligación. 
bidamente interpretado, pone de cargo del deudor la infracción originada en la conducta de las personas que por su iniciativa tienen influencia en el cumplimiento de su obligación ${ }^{165}$.

Por último, cabe destacar que, entre los autores chilenos, Claro Solar se acerca bastante a las ideas planteadas en las líneas anteriores cuando afirma que "es necesario que el deudor responda de una manera absoluta del hecho de sus auxiliares. Debe soportar el riesgo de la inejecución por la culpa de las personas que se ve obligado a emplear. Este riesgo es para él un pasivo de la empresa que debe tomar en cuenta como otras eventualidades desfavorables", agregando luego que "no constituye este riesgo un caso fortuito o de fuerza mayor" 166 .

ii) En seguida se presenta la categoría de los riesgos vinculados con los medios empleados por el empresario en la preparación y ejecución de su prestación.

Junto con la intervención de los diversos sujetos señalados en el apartado anterior, el empresario también pone en marcha -para el desarrollo de su actividad- un conjunto de medios o recursos tangibles e intangibles, que forman parte de su estructura organizacional. La suficiencia y buen

${ }^{165} \mathrm{Y}$ ello con independencia de cualquier valoración de la conducta del deudor o del tercero. Es decir, no es necesario establecer si ha habido culpa de alguno de ellos. Tal circunstancia es irrelevante si se parte de la base de que la participación de terceros es un riesgo que el deudor que opta por recurrir a ellos asume al contratar, y que por lo tanto, debe cargar a todo evento. En nuestra doctrina, Claro Solar y Abeliuk expresamente exigen la culpa del tercero. Sin embargo, el último autor deja abierta la cuestión relativa al fundamento de la responsabilidad del deudor, limitándose a sostener la posibilidad de fundarla en la idea de riesgo o bien, en la culpa in vigilando o in eligendo en que éste incurriría, la que constituye la justificación de la misma según quienes conciben la responsabilidad contractual en términos estrictamente subjetivos. Al respecto, cabe tener en cuenta que en España Badosa, no obstante concebir subjetivamente el régimen de responsabilidad contractual, al pronunciarse respecto de la responsabilidad del posadero, la plantea en términos objetivos, recurriendo precisamente a la idea de riesgos, pues afirma que ella deriva del hecho de que la introducción de terceros se hace a riesgo del deudor, rechazando la culpa in vigilando como fundamento de la misma. Cfr. BADOSA, Ferrán, La diligencia y la culpa del deudor en la obligación civil (Bolonia, 1987), p. 774.

${ }^{166}$ Claro Solar, Luis, cit. (n. 14), p. 54. En un sentido muy similar se expresa FuenZalida, Sergio, cit. (n. 138), pp. 114-115, quien sobre el fundamento de esta responsabilidad en nuestro Derecho, afirma que ella se justifica en dos órdenes de consideraciones: en primer lugar, unas de orden jurídico, que expresa diciendo que "el hecho o culpa del deudor se extiende al de sus auxiliares"; y en segundo término, otras de carácter económico, que se traducen en la constatación de la realidad, que en la mayoría de los casos pone al deudor en la necesidad de recurrir a terceras personas para dar cumplimiento a sus obligaciones, siendo la actuación de ayudantes y sustitutos indispensable para el desarrollo de ciertas empresas. 
estado de éstos es fundamental para el correcto desempeño de las tareas de preparación, planificación y ejecución de las prestaciones de las que el empresario es deudor.

Dentro de dichos medios se encuentran las maquinarias, herramientas; las instalaciones de diversos orden: eléctricas, sanitarias, de seguridad; los servicios necesarios para el funcionamiento de la empresa ${ }^{167}$; los equipos y recursos tecnológicos utilizados en su actividad: computadores, impresoras, programas computacionales, redes de comunicación internas, etc.; los medios de transporte empleados, entre otros. La variedad y particularidades de cada uno de estos instrumentos dependerán del giro específico de la empresa de que se trate. Cada actividad productiva y de intermediación de bienes y servicios supone el montaje de un aparato instrumental distinto, cuyo correcto estado de mantención y funcionamiento es de cargo del empresario. Por lo mismo, el riesgo de que un incumplimiento tenga su origen en un desperfecto de alguno de estos elementos pertenece la esfera de riesgos que por el contrato el deudor debe asumir y controlar ${ }^{168}$.

Así, por ejemplo, si una empresa que fabrica y distribuye zapatos emplea para su gestión un determinado sistema computacional -por ejemplo, el

${ }^{167}$ Hay que distinguir entre la actividad del proveedor del servicio, por ejemplo, una empresa de "internet", que forma parte de la primera categoría de riesgos; y la necesidad de que el empresario se encargue de mantener disponible el mismo, en el caso propuesto, pagando oportunamente la cuenta.

${ }^{168}$ En alguna medida se acerca a esta idea la sentencia de la Corte de Apelaciones de La Serena de 12 de diciembre de 2006, cit. (n. 1). Se trata de una demanda interpuesta en contra del arrendatario de un inmueble, reclamando la indemnización de los perjuicios causados por la destrucción de éste a causa de un incendio. El demandado alegó que el referido incendio era constitutivo de caso fortuito. Al pronunciarse sobre sus requisitos, la Corte afirma que no cumple con la primera exigencia de éste expresando: "En efecto, es un hecho de la causa que el incendio se originó en el interior del inmueble arrendado, cuando el arrendatario y su personal celebraban una convivencia por el día del trabajo, permaneciendo el local cerrado para el acceso de público. El fuego se originó por la inflamación de la máquina freidora ubicada en la cocina, hecho ocurrido mientras celebraban su convivencia. Así lo corroboran tanto los testigos de la propia demandada y del actor, como el informe del Comandante del Cuerpo de Bomberos. Siendo ello así, falta el primer elemento del caso fortuito, toda vez que no es posible sostener que el fuego o incendio haya sido ajeno al deudor". Aunque el tribunal previamente había expresado la exigencia de exterioridad en términos más bien subjetivos, señalando que debía tratarse de un hecho ajeno a la voluntad de las partes, por la forma en que fundamenta la ausencia del requisito parece acercarse a lo aquí sostenido. En efecto, señala como causa del rechazo el desperfecto de un objeto empleado por el deudor. Ello puede entenderse comprendido en el cumplimiento de su obligación de conservar la cosa arrendada, y por ende, en los riesgos asumidos por el deudor al contratar. 
denominado SAP, de gran uso en la actualidad-corre con el riesgo de que un incumplimiento pueda producirse en razón de una falla del mismo. Así, puede suceder que los datos que el referido sistema arroja sobre las existencias de la empresa no sean exactos, por lo que la entrega de un determinado número de pares de zapatos pactada para una cierta fecha no pueda cumplirse íntegramente, debido a la falta de productos en la cantidad acordada. En tal situación, es lógico que por la interpretación del contrato se concluya que el defecto del sistema computacional de gestión es un riesgo de la empresa deudora, la que frente a su acreedor se presenta como conocedora de su negocio y, por lo tanto, con capacidad de control de lo que su administración implica, debiendo asumir las consecuencias de una deficiencia interna de su organización.

Nuestro derecho no desconoce esta idea. De hecho, el Código Civil la recoge en más de una norma. Así se puede apreciar en su artículo 2015 inciso $1^{\circ}$, que en materia de contrato de transporte, impone al acarreador una obligación de seguridad, haciéndole responsable del daño que sobrevenga a la persona como consecuencia de la mala calidad del carruaje, barco o navío en que se verifique el transporte. En dicha disposición, el legislador reconoce implícitamente que el estado de los instrumentos -en el caso concreto, el medio de transporte- destinados por el empresario al desarrollo de su actividad, y utilizados en el cumplimiento de las obligaciones contraídas, constituye un riesgo que por el contrato pertenece al transportista ${ }^{169}$. Algo similar se advierte en el artículo 2003, relativo al contrato de obra cuyo objeto es la construcción de edificios. La regla tercera de dicha disposición establece la responsabilidad del empresario por el perecimiento o amenaza de ruina del edificio dentro de los cinco años subsiguientes a su entrega derivado del vicio de los materiales. Bien

${ }^{169}$ En particular, este supuesto se refiere al incumplimiento del deber de seguridad que pesa sobre el transportista y que le impone resguardar la integridad física de sus pasajeros. Uno de los elementos fundamentales para el cumplimiento de dicho deber es el correcto estado del medio utilizado en el traslado. La mala calidad de éste es lógicamente un riesgo que la propia naturaleza del contrato -al dar lugar a este deber de seguridad- impide considerar ajeno al deudor. Algo similar ocurre en los contratos de atención médica, que también dan lugar a un deber de protección a favor del paciente, y así por ejemplo, tratándose de aquellos celebrados con clínicas u hospitales -deudor empresario- dicho deber comprende el buen estado de las instalaciones y correcto funcionamiento del instrumental médico utilizado en la atención de los pacientes, de modo de garantizar la protección de su integridad física. Si un daño se deriva de un defecto de mantenimiento de aquellos, por ejemplo, de un aparato de respiración artificial, se trata de la concreción de un riesgo típico de la actividad del deudor -clínica u hospital- y por consiguiente, no puede invocarse la concurrencia de un caso fortuito. 
puede afirmarse que esta norma descansa en la idea de que los incumplimientos originados en los medios o recursos empleados por el empresario corresponden a la realización de un riesgo que, al derivar de su actividad profesional, pertenece típicamente a aquel.

Y por último, fuera del Código Civil, en la Ley No 19.496 sobre derechos del consumidor, el artículo 20, letra c) también admite la interpretación aquí sostenida. El citado artículo regula diversos supuestos de incumplimiento contractual, estableciendo la llamada garantía legal a favor del consumidor ${ }^{170}$, junto a la que admite también la responsabilidad del proveedor, que se traduce en la indemnización de perjuicios. En particular, interesa destacar su letra c) ${ }^{171}$, que hace procedente las mismas cuando "cualquier producto, por deficiencias de fabricación, elaboración, materiales, partes, piezas, elementos, sustancias, ingredientes, estructura, calidad o condiciones sanitarias, en su caso, no sea enteramente apto para el uso o consumo al que está destinado o al que el proveedor hubiese señalado en su publicidad'. Claramente, en esta norma está presente la idea de que el estado de los medios materiales o inmateriales a través de los cuales el deudor prepara y ejecuta su prestación es un riesgo típico de su actividad, lo que puede sostenerse tanto para la procedencia de la garantía legal como para la indemnización de perjuicios ${ }^{172}$. Ambos operan sin que el proveedor pueda

${ }^{170}$ Se trata del Derecho de opción que se entrega al consumidor en los supuestos previstos en la norma, y que comprende la posibilidad de exigir la reparación gratuita del bien, su sustitución o la devolución de la cantidad pagada.

${ }^{171}$ Destaco la referida letra c) porque en ella se puede advertir una relación directa con la segunda categoría en que he dividido los riesgos típicos de un deudor empresario: la de los medios empleados en la preparación y ejecución de su prestación.

${ }^{172}$ En nuestra doctrina, Corral Talciani se muestra contrario a esta idea por cuanto a su juicio, debe separarse la responsabilidad derivada de la garantía legal, de aquella que se traduce en la indemnización de perjuicios por el incumplimiento. De acuerdo a este autor, la primera sería de carácter objetivo y no admitiría la alegación del caso fortuito; en cambio, la indemnización de perjuicios quedaría sujeta a las reglas generales, siendo por tanto una responsabilidad subjetiva en que sí podría exonerarse el proveedor invocando el caso fortuito. CoRRAL TALCIANI, Hernán, Ley de protección al consumidor y responsabilidad civil por productos y servicios defectuosos, en Derecho del consumo y protección al consumidor: estudios sobre la Ley $N^{o} 19.496$ y las principales tendencias extranjeras, CEJ. 3 (1999), p. 179-180. Por mi parte-sin perjuicio de considerar que, tratándose de la garantía legal, en estricto rigor no cabe hablar de responsabilidad, pues ésta corresponde exclusivamente a la obligación indemnizatoria nacida del incumplimiento- creo que si se concibe la exterioridad del caso fortuito en los términos propuestos en este trabajo, no hay obstáculo para entender que el mismo no procede tampoco frente a la pretensión indemnizatoria, precisamente por no provenir el incumplimiento de un riesgo ajeno al deudor. Por su parte, Rodríguez Grez también califica el supuesto descrito como un caso de responsabilidad objetiva 
alegar un caso fortuito, porque el incumplimiento no deriva de un hecho ajeno a los riesgos que en virtud del contrato son de su cargo.

\section{Conclusión: la exterioridad como ajeneidad del hecho al ámbito de} riesgos determinado en el contrato.

A partir de todo lo expresado, se puede afirmar que la definición de la exterioridad en el caso fortuito supone necesariamente considerar la distribución del riesgo del incumplimiento realizada por las partes a través del propio contrato. Al celebrarlo, ellas fijan un ámbito conformado por los riesgos que cada una asume, de modo tal que todo evento que afecte el cumplimiento y que pertenezca al mismo, no podrá ser calificado como caso fortuito por no cumplir el requisito de exterioridad. Dicho ámbito de riesgos constituye entonces el punto de referencia que esta exigencia necesita para su definición.

En efecto, la simple idea de que la contratación -en razón del intercambio económico y generalmente futuro que le subyace- envuelve una serie de riesgos, entre los cuales se encuentra el de un eventual incumplimiento de alguna de las prestaciones, conduce a concluir que el contrato cumple la función de distribuirlos entre las partes. A través de sus propias estipulaciones, éstas reparten dicho riesgo, de modo tal que el contrato es un instrumento fundamental en la tarea de establecer, una vez ocurrido el incumplimiento, si el evento causante del mismo es o no ajeno al deudor. La calificación de la exterioridad del hecho supone, por lo tanto, una labor de interpretación del contrato. De ésta se concluye que toda actividad de cumplimiento implica un riesgo típico, que constituye el contenido mínimo o básico de la esfera de riesgos que el contrato define. Dentro de la misma, no cabe la posibilidad de exoneración, porque la convención ha puesto de cargo del deudor el manejo y control de los riesgos que lo integran. Los riesgos comprendidos en el mismo no son externos al deudor, no pudiendo configurar por lo tanto un caso fortuito.

La pregunta por la concurrencia de un caso fortuito sólo tiene sentido más allá de ese ámbito de riesgos que se desprende del contrato. Solamente en la medida que el incumplimiento se ubique fuera de dicho margen, se puede dar por satisfecho el requisito de la exterioridad, y habrá que determinar entonces si, además, se cumplen las otras dos exigencias previstas en el artículo 45 CC., es decir, habrá que establecer si el hecho, junto con ser ajeno a la esfera de riesgos del deudor, puede también ser calificado como imprevisible e irresistible.

en materia contractual, sin distinguir entre el Derecho de opción por garantía y la indemnización de perjuicios. Rodríguez Grez, Pablo, cit. (n. 14), p. 161. 
Esta forma de concebir la exterioridad, le atribuye autonomía y contenido propio como requisito del caso fortuito. En efecto, deja de ser considerada -como ha ocurrido en nuestro país y también en el Derecho comparado- como la consecuencia de la imprevisibilidad e irresistibilidad del evento y equivalente, por tanto, a la inimputabilidad o ausencia de culpa del deudor. Por el contrario, la exterioridad se construye objetivamente porque la diligencia no desempeña papel alguno en la definición de la esfera de riesgos cuya asunción compete al deudor ${ }^{173}$. Ésta se determina exclusivamente a partir del contenido del contrato, en base a una interpretación integradora del mismo, hecha en los términos ya expresados. De esta forma, el hecho será ajeno cuando no constituya un riesgo que según el contrato corresponda al deudor. Esto implica, al mismo tiempo, incorporar una nota objetiva en el concepto mismo de caso fortuito, pues, al entenderse la exterioridad en la forma señalada, debe descartarse que éste se traduzca simplemente en la negación de culpa del deudor, pues deja de definirse exclusivamente a partir de la valoración de la conducta de este último.

Por otra parte, entender la exterioridad en el sentido recién descrito, conduce a que el caso fortuito opere también como un medio para atribuir responsabilidad al deudor. O dicho en otros términos, revela que el criterio para la asignación de ésta no está constituido exclusivamente por la culpa. Y esto es así porque si la verificación del caso fortuito sólo es posible fuera del margen de riesgos determinado a partir del contrato, todo aquello que no sea externo al deudor, es decir, todo lo que, por estar comprendido en la referida esfera de riesgos, no sea susceptible de ser calificado como ajeno, supone responsabilidad para aquel por la falta de exacto y oportuno

${ }^{173}$ En este sentido se pronuncia expresamente en España Del Olmo, quien afirma que la diligencia es irrelevante a los efectos de determinar la esfera de control. Según la autora, al determinar esta última "no se introduce un juicio a posteriori sobre la previsión o evitabilidad del evento impeditivo con arreglo a la diligencia, sino que el juicio se refiere a lo establecido en el contrato y a la esfera de organización del deudor, atendiendo al tipo contractual concreto", planteamiento que comparto completamente. Del Olmo Guarido, Natalia, cit. (n. 33), p. 202, nota 88. Una idea contraria se desprende de las afirmaciones de Díez-Picazo cuando refiriéndose a la interpretación del concepto de caso fortuito como hecho ubicado fuera del marco de control del deudor, afirma que dicho marco guarda una evidente relación con el tipo de diligencia que le sea exigible al deudor, variando según la diligencia sea la de una persona media, o de un profesional o un empresario. DíEz-PiCAZo, Luis, Fundamentos, cit. (n. 65), p. 727. En mi opinión, si el caso fortuito se construye a partir de la idea de esfera de control, y ésta a su vez, se define conforme a la diligencia, entonces no se llega a una noción objetiva de la causa de exoneración, que se mantiene así en directa dependencia de la diligencia exigible. 
cumplimiento ${ }^{174}$. A partir de la noción de exterioridad planteada, el caso fortuito expresa el límite entre aquellos hechos que por no ser extraños al deudor son de su cargo y aquellos que por serlo reúnen la primera exigencia necesaria para la exoneración. Tratándose de los primeros, el deudor debe responder por el incumplimiento, y en ese sentido la noción de caso fortuito explica al mismo tiempo la atribución de responsabilidad ${ }^{175}$.

Por último, cabe reiterar que en el Código Civil chileno existen diversas normas -especialmente dentro de la regulación particular de ciertos contra$\operatorname{tos}^{176}$ - que permiten acoger la idea de exterioridad del caso fortuito como ajeneidad del hecho que lo constituye a los riesgos que el propio contrato asigna al deudor. Además de las disposiciones ya citadas en líneas anteriores, especial relevancia presentan en este sentido los supuestos regulados en los artículos 2242 y 2243 , referidos a la responsabilidad que afecta al posadero por los efectos que los huéspedes depositen en la posada. Estas normas ponen de manifiesto, de manera especialmente clara, que la intervención de otras personas en las tareas de organización, preparación y ejecución de la prestación debida forma parte del riesgo típico de todo deudor ${ }^{177}$.

${ }^{174}$ En este sentido, cabe tener en cuenta lo expresado por Exner, quien afirma que del contenido y extensión del concepto de fuerza mayor depende el alcance de la responsabilidad del deudor. EXNER, Adolf, cit. (n. 40), p. 16. Si bien su afirmación se refiere al ámbito específico de contratos para los que postula su tesis, es perfectamente aplicable a la noción de exterioridad del caso fortuito propuesta en el presente trabajo.

${ }^{175}$ Igualmente es necesario tener en cuenta que, como la definición de lo que no es externo al deudor se encuentra en el contrato, en definitiva la base de la responsabilidad del deudor se encuentra en la propia convención, de modo tal que el contenido de ésta constituye la fuente primaria de la responsabilidad.

${ }^{176}$ Sobre la importancia de considerar las normas contenidas en la regulación particular de los contratos, se pronuncia en España Díez-Picazo, quien afirma que para perfilar el sistema y los principios rectores de responsabilidad contractual en el Derecho positivo español es necesario prestar atención no sólo a las reglas generales existentes en la materia, sino que antes deben estudiarse los regímenes particulares de cada tipo contractual. El autor afirma que el examen del articulado del Código Civil español pone de manifiesto la superposición de dos estratos de origen histórico diverso: en primer término, aparecen las reglas generales en la materia, y en un segundo nivel, se encuentra la regulación de los contratos en particular, caracterizada por un gran casuismo. Mientras este último es herencia del Derecho romano clásico, las reglas generales son el resultado de las reelaboraciones a que aquel fue sometido. De ahí que considera necesario tomar como punto de partida del estudio de la materia, los aludidos regímenes especiales. Díez-Picazo, Luis, Fundamentos, cit. (n. 65), pp. 715 ss. Las reflexiones del autor español son plenamente pertinentes en nuestro sistema, por cuanto algo similar ocurre con la regulación del Código Civil de Chile.

${ }^{177}$ Las normas que resultan de interés respecto de la segunda categoría integrante del riesgo típico del deudor empresario -constituida por los medios o herramientas 
La primera de las normas citadas, el artículo 2242 CC., dispone: " $E l$ posadero es responsable de todo daño que se cause a dichos efectos [los que el huésped haya introducido en la posada, entregándolos al posadero o a sus dependientes, según el artículo 2241] por culpa suya o de sus dependientes, o de los extraños que visitan la posada, y hasta de los hurtos y robos; pero no de fuerza mayor o caso fortuito, salvo que se le pueda imputar a culpa o dolo". ¿Qué interpretación puede hacerse de esta disposición? Pues bien, claramente puede desprenderse la consideración del caso fortuito -causa de exoneración del posadero expresamente prevista en el citado artículocomo un hecho que debe ser ajeno a los riesgos que el propio contrato supone para el deudor. El contrato de hospedaje involucra al mismo tiempo el depósito en manos del posadero de los efectos introducidos por los viajeros en la posada, lo que obliga a considerar, como parte de los riesgos que a aquel corresponden en razón de la convención, la posibilidad de que dichos efectos sean dañados por culpa de sus dependientes ${ }^{178}$, o de terceros extraños que visitan la posada ${ }^{179}$. Lo mismo ocurre con los eventuales hurtos y robos de los referidos efectos, sin que interese el autor de tales delitos y además, sin exigencias de carácter subjetivo en relación a la verificación de dichos hechos ${ }^{180}$. Según se desprende del tenor de la disposición, las contingencias mencionadas no constituyen caso fortuito para el posadero, lo que puede explicarse precisamente porque la propia

empleadas en la actividad desarrollada para ejecutar su prestación- fueron aludidas en dicha oportunidad.

${ }^{178}$ Guzmán afirma que, tratándose de los daños inferidos en los efectos del huésped, la responsabilidad establecida para el posadero en esta disposición es objetiva, por cuanto no se requiere su culpa; pero no lo es en cuanto, al exigirse la culpa de las personas por las que el posadero es responsable, éste podría exonerarse probando que el hecho de tales personas no fue culpable. GuZMÁn BRITO, Alejandro, La responsabilidad objetiva por custodia en el Derecho romano y en el Derecho moderno, con una referencia especial a la regla "periculum est emptoris", en RChD. 24(1997)1, p. 190.

${ }^{179}$ Guzmán destaca el sentido amplio que del tenor de la disposición se desprende en relación a la expresión "extraños" que utiliza la norma, sólo limitada por la exigencia de que visiten la posada. Esto permite comprender en dicha noción, según el autor, a los huéspedes alojados; a los que sin ser alojados ingresan en la posada para valerse de otro servicio de la misma o para inquirir información sobre tales servicios; o quienes ingresan a saludar al posadero, a sus dependientes, a algún huésped o a alguien que se encuentre ocasionalmente en su interior. GuZMÁn BRITO, Alejandro, cit. (n. 178) p. 189.

${ }^{180}$ En efecto, según la norma la responsabilidad del posadero por hurtos y robos no depende de quien haya cometido el delito, pudiendo ser cualquier persona, y no sólo los dependientes o extraños que visitan la posada, y sin que interese en este caso considerar si ha habido culpa del posadero o de las otras personas mencionadas en la disposición. 
naturaleza del contrato conduce a calificarlos como riesgos que quedan de su cargo y que por tanto, no autorizan su exoneración ${ }^{181}$.

Por su parte, el artículo 2243 CC. es más claro aún, al disponer: "el posadero es además obligado a la seguridad de los efectos que el alojado conserva alrededor de sí. Bajo este respecto, es responsable del daño causado o del hurto o robo cometido por los sirvientes de la posada o por personas extrañas que no sean familiares o visitantes del alojado". Los riesgos descritos en la disposición no pueden constituir un caso fortuito respecto del posadero. ¿Por qué? La respuesta es clara: no se trata de riesgos ajenos al posadero en razón del contrato. El incumplimiento de la obligación de seguridad que rige respecto de las pertenencias de los viajeros, como consecuencia de la acción de las personas aludidas en la norma, es una contingencia inherente a la actividad profesional que aquel realiza, y que por lo mismo, debe asumir ${ }^{182}$.

Además, el contenido de las normas examinadas se puede explicar también porque están referidas a un deudor con las características de empresario $^{183}$. Quien desarrolla el negocio de hospedaje pone en marcha

${ }^{181}$ La idea de distribución de riesgos que todo contrato implica aparece detrás de la disposición aludida, y en el caso particular, supone que el posadero cargue con los riesgos mencionados en ella, porque debe estar en control de los mismos. En este sentido cabe tener presente lo afirmado por Badosa, quien sostiene que la responsabilidad del hospedero no procede de culpa, sino que tiene un fundamento específico: su poder de control sobre el local. BADOSA, Ferrán, La diligencia, cit. (n. 165), p. 461. Por otra parte, esta idea se refuerza si se considera el origen histórico de esta norma, que no es sino una manifestación de la responsabilidad por custodia del Derecho romano clásico, la que se caracterizaba precisamente por constituir un régimen objetivo de responsabilidad, que en definitiva implicaba poner de cargo del deudor ciertos riesgos que no se consideraban comprendidos en la categoría de vis maior. Guzmán destaca que la fuente de la disposición se encuentra, según lo indicado por don Andrés Bello, en la ley $26^{\mathrm{a}}$, título $8^{\circ}$, partida V. Ello permitió que llegara al Código la figura de la custodia derivada del receptum romano. Según este autor, tratándose de los hurtos y robos, se está en presencia de la supervivencia de una de las hipótesis de responsabilidad por custodia del Derecho romano clásico; mientras que en el caso de los daños, la recepción es parcial, debido a la ausencia de exigencias subjetivas en dicho Derecho. GuZMÁn Brito, Alejandro, La responsabilidad, cit. (n. 178), pp. 188-191.

${ }^{182}$ Asimismo, cabe destacar que -a diferencia de la norma anterior, en que se alude a la culpa del posadero o de las otras personas mencionadas- el artículo 2243 CC. establece la responsabilidad sin mencionar la culpa, quedando con ello en evidencia que para el legislador se trata simplemente de una cuestión de riesgos, en que la culpa no desempeña ningún rol.

${ }^{183}$ De hecho, hay que tener en cuenta lo dispuesto por el artículo 2248 CC., que cierra el párrafo, y que hace extensivas las normas citadas a otros establecimientos que caben también en el concepto de empresa. 
una organización más o menos compleja, que indudablemente supone la asunción por su parte de determinados riesgos, cuya concreción no puede dar lugar a un caso fortuito.

Las conclusiones extraídas a partir de las normas citadas, son aplicables a todos los casos en que el Código Civil dispone la responsabilidad del deudor por otras personas que han dado lugar a un incumplimiento de su parte, sea auxiliares $\mathrm{u}$ otros terceros ${ }^{184}$. Y en general, permiten confirmar la idea planteada en estas líneas en el sentido que la exterioridad del caso fortuito debe ser construida a partir del contenido del contrato, siendo entendida como ajeneidad respecto de aquellos riesgos -tanto personales como materiales- que, conforme a una interpretación integradora del mismo, pueden estimarse como asumidos por el deudor. Sólo los hechos que se ubiquen fuera de la esfera de riesgos delimitada por el contrato, cumplen con la primera exigencia necesaria para constituir un caso fortuito.

[Recibido el 29 de octubre y aceptado el 30 octubre de 2009]

\section{BIBLIOGRAFÍA}

Abeliuk Manasevich, René, Las Obligaciones² (Santiago, 1983).

Alessandri, Arturo, Teoría de las Obligaciones (Santiago, 1930).

Alessandri, Arturo; Somarriva, Manuel; Vodanovic, Antonio, Tratado de las Obligaciones $^{2}$ (Santiago, 2004).

AlPA, Guido, Rischio contrattuale, en CIE. 2(1986).

AlPa, Guido; Bessone, Mario; Roppo, Enzo, Rischio contrattuale e autonomia privata (Nápoles, 1982).

AnElLi, Franco, Caso fortuito e rischio di impresa nella responsabilitá del vettore (Milán, 1990).

Antonmattei, Paul- Henri, Contribution à l'étude de la force majeure (París, 1992).

AтіYAн, Patrick Selim, An introduction to the law of contract (Oxford, 1995).

BADOSA, Ferrán, La diligencia y la culpa del deudor en la obligación civil (Bolonia, 1987).

Badosa, Ferrán, Artículo 1105, en Paz-Ares, Cándido et alii (a cura di), Comentarios del Código Civil II (Madrid, 1993).

BARAONA GONZÁLEZ, Jorge, Responsabilidad contractual y factores de imputación de daños: apuntes para una relectura en clave objetiva, en RCHD. 24 (1997) 1.

BARAONA GONZÁlez, Jorge, El retraso en el cumplimiento de las obligaciones (Madrid, 1998).

BARros Bourie, Enrique, La diferencia entre "estar obligado" y "ser responsable" en el

${ }^{184}$ En todos esos supuestos, lo que está detrás en definitiva es la idea de que el contrato ha puesto de cargo de esos deudores el riesgo de que el incumplimiento sea originado por alguna de dichas personas. 
derecho de los contratos, en Corral Talciani, Hernán; Rodríguez Pinto, María Sara (a cura di), Estudios de Derecho Civil, II (Santiago, 2006).

Barros Errázuriz, Alfredo, Curso de derecho civil, segundo año: De las obligaciones en general (Santiago, 1932).

Bercovitz Rodríguez-Cano, Rodrigo (a cura di), Manual de derecho civil. Obligaciones (Madrid, 2003).

BernsteIn, Herbert; LoOKFosky, Joseph, Understanding the CISG in Europe (La Haya, 1997).

Bessone, Mario, Adempimento e rischio contrattuale (Milán, 1969).

BetTi, Emilio, Teoría General de las Obligaciones (trad. cast., Madrid, 1970).

Bonell, Michael, Force Majeure e hardship nel dirito uniforme della vendita internazionale, en Diritto del commercio internazionale (Roma, 1990).

Borrell y Soler, Antonio María, Cumplimiento, incumplimiento y extinción de las obligaciones contractuales civiles (Barcelona, 1954).

Carrasco Perera, Ángel Francisco, Artículo 1105 Código Civil, en Albaladejo, Manuel (a cura di), Comentarios al Código Civil y Compilaciones Forales (Madrid, 1989).

Castilla Barea, Margarita, Comentario a la STS de 14 de marzo de 2001, en CCJC. 58 (2002).

Castronovo, C., Tra rischio e caso fortuito. La responsabilità da cassette di sicurezza, en BBTC. 1(1978).

Castrovinci, Dario, Il problema della inesigibilità della prestazione, en GC. (1988) 2.

Chironi, G.P., Culpa en el derecho civil moderno. La culpa contractual (Madrid, 1928).

Claro Solar, Luis, Explicaciones de derecho civil chileno y comparado (Santiago, 1978, reimpresión de la segunda edición), X y XII.

Comporti, Mario, Causa estranea, caso fortuito, responsabilità oggetiva, en FI. 2 (1985) 1.

Corral Talciani, Hernán, Ley de protección al consumidor y responsabilidad civil por productos y servicios defectuosos, en Derecho del consumo y protección al consumidor: estudios sobre la ley $N^{o} 19.496$ y las principales tendencias extranjeras, CEJ. 3 (1999).

Cottino, Gastone, Voz caso fortuito e forza Maggiore, en Enciclopedia del Diritto VI (Milán, 1960).

COUSTASSE, Alberto; ITURRA, Fernando, El caso fortuito ante el derecho civil (Santiago, 1958).

CRISTÓBAL MONTES, Ángel, La imposibilidad sobrevenida de la prestación en la obligación alternativa, en $R D P r$. (1995).

Del Olmo Guarido, Natalia, El caso fortuito: su incidencia en la ejecución de las obligaciones. Doctrina y jurisprudencia (Navarra, 2004).

Díez-PiCAzo, Luis, Fundamentos del Derecho Civil Patrimonial II: Las relaciones obligatorias $^{6}$ (Madrid, 2008).

Elorriaga De Bonis, Fabián, Teoría de los riesgos, en Estudios sobre reformas al Código Civil y Código de Comercio (Santiago, 2002).

EsMEIN, M. Paul, Le fondement de la responsabilité contractuelle rapproché de la responsabilité délictuelle, en RTDC. 32 (1933).

EXNER, Adolf, La fuerza mayor en el derecho mercantil romano y en el actual (Trad. español, Madrid, 1905). 
Farnsworth, E. Allan, Contracts ${ }^{2}$ (Boston, 1990).

FERRARINI, Guido, Il controllo del rischi come criterio di responsabilità nella vendita internazionale, en QGC. 39 (1981).

FuenZalida, Sergio, Los terceros en la responsabilidad contractual, en RDJ. 57 (1960), primera parte.

Fueyo Laneri, Fernando, Derecho Civil, IV: De las obligaciones (Santiago, 1958), I.

Gatica PaCHECO, Sergio, Aspectos de la indemnización de perjuicios por incumplimiento de contrato (Santiago, 1959).

Gavidia, Julio, Presuposición y riesgo contractual, en ADC. 40 (1987) 2.

GUZMÁN BRITO, Alejandro, La responsabilidad objetiva por custodia en el derecho romano $y$ en el derecho moderno, con una referencia especial a la regla periculum est emptoris, en RCHD. 24(1997) 1.

Honnold, John, Uniform Law for International Sales ${ }^{3}$ (La Haya, 1999).

Huc, Téophile, Commentaire théorique et pratique du code civil 7(Paris, 1892).

JoRdANO FRAGA, Francisco, Las reglas generales de la responsabilidad civil contractual en el sistema del Código Civil español, en ADC. 38 (Madrid, 1985).

Lacruz Berdejo, José Luis et alii, Elementos de Derecho Civil. Derecho de Obligaciones. Parte General. Teoría General del Contrato, II (Barcelona, 1994) I.

LARENZ, Karl, Derecho de obligaciones (Madrid, 1958).

Larraín Ríos, Hernán, Teoría General de las Obligaciones (Santiago, 2002).

Llamas Pombo, Eugenio, Artículo 1105, en Pasquau Liaño, Miguel (a cura di), Jurisprudencia Civil Comentada. Código Civil II (Granada, 2000).

López Santa María, Jorge, Los Contratos. Parte General II (Santiago, 2005).

Manresa, José María, Comentarios al Código Civil. Artículo $1105^{6}$ VIII (Madrid, 1967) I.

Mazeaud, Henri; Mazeaud, León; Mazeaud, Jean, Lecciones de derecho civil (Buenos Aires, 1962) II.

Meza Barros, Ramón, Manual de derecho civil' (Santiago, 1997).

Montes Penadés, Vicente, El incumplimiento de la obligación, en Valpuesta FernánDEZ, María del Rosario (a cura di), Derecho de obligaciones y $\operatorname{contratos}^{2}$ (Valencia, 1995).

Morales Moreno, Antonio Manuel, Artículo 35, en Díez-Picazo y Ponce de León, Luis (a cura di), La compraventa internacional de mercaderías. Comentario de la Convención de Viena (Madrid, 1998).

Moreno Quesada, Bernardo, Problemática de las obligaciones de hacer, en RDPr. (1976).

Orlando, Salvatore, Rischio e vendita internazionale (Milán, 2002).

Pantaleón, Fernando, El sistema de responsabilidad contractual. Materiales para un debate, en $A D C .44(1991) 3$.

Pichonnaz, Pascal, Impossibilité et exorbitante. Étude analytique des obstacles à l'exécution des obligations en droit suisse (Friburgo, 1997).

PiZARRo Wilson, Carlos, Étude critique sur la responsabilité contractuelle en droit positif chilien (tesis doctoral, Université Pantheon-Assas, París, 2003).

Pizarro Wilson, Carlos, La fuerza mayor como defensa del deudor. A propósito de la restricción del suministro de gas a Chile, en GJ. 288 (2004).

Planiol, Marcel; RIPERT, Georges, Traité pratique de droit civil français. Obligations VI (París, 1931). 
Ponzanelli, Giulio, Articolo 79, en Bianca, Cesare (a cura di), Convenzione di Vienna sui contratti di vendita internazionale di beni mobili (Padova, 1992).

Posner, Richard, Análisis económico del derecho (Trad. cast., México, 1998).

Pothier, Robert Joseph, Tratado de las Obligaciones (Trad. cast. Buenos Aires, 1993).

Realmonte, Franceso, Caso fortuito e forza Maggiore, en JUS (Milán, 1987) 3.

RIPERT Georges; Boulanger, Jean, Tratado de derecho civil según el tratado de Planiol IV (Buenos Aires, 1956) I.

Rodríguez Grez, Pablo, Responsabilidad contractual (Santiago, 2003).

Rogron, Joseph-André, Les Codes français expliqués (Paris, 1836).

Roppo, Enzo, Il contratto (Bolonia, 1977).

Roppo, Enzo, Obbligazioni e contratti, en Bessone, Mario (a cura di), Casi e questioni di diritto privato. Obbligazioni e contratti; Responsabilità civile III(Milán, 1987).

Salvador Coderch, Pablo, Comentario Artículo 79 CSIG, en Díez-Picazo y Ponce DE LEÓN, Luis (a cura di), La compraventa Internacional de mercaderías (Madrid, 1998).

SCHÄFer, Hans-Bernd; Отt, Claus, Manual de análisis económico del derecho civil (Madrid, 1991).

Stoll, Hans; Gruber, Georg, Article 79, en Schlechtriem, Peter (a cura di), Commentary on the UN Convention the International Sale of Goods (1986, trad. inglés, 2006).

Stoll, Hans, Article 79, en Schlechtriem, Peter (a cura di), Commentary on the UN Convention the International Sale of Goods ${ }^{2}$ (Oxford, 1986 trad. inglés 1998).

Torralba, Orencio, La responsabilidad por los auxiliares en el cumplimiento de las obligaciones, en $A D C .24$ (1971) 4.

Torres López, Juan, Análisis económico del derecho. Panorama doctrinal (Madrid, 1987).

Treitel, G.H, Frustration and force majeure (Londres, 1994).

TRIMARCHI, Pietro, Il caso fortuito quale limite della responsabilità peri l danno da cose, en RTDPC. (1959) 2.

Trimarchi, Pietro, Rischio e responsabilità oggettiva (Milán, 1961)

Trimarchi, Pietro, Sul significato economico dei criteri di responsabilità contrattuale, en RTDPC. (Milán, 1970) 1.

Vial del Río, Víctor Manuel, Manual del derecho de las obligaciones en el Código Civil Chileno (Santiago, 2003).

Vidal Olivares, Álvaro, Criterios de atribución de responsabilidad por daños en la Compraventa Internacional de Mercaderías (Tesis Doctoral, Universidad Autónoma de Madrid, Madrid, 1999).

Vidal Olivares, Álvaro, La construcción de la regla contractual en el derecho civil de los contratos, en RDUCV. 21 (2000).

VIDAL OlIVARES, Álvaro, Atribución y exoneración de responsabilidad en la compraventa internacional, en RDUAs. 18 (2005)1.

VISINTINI, Giovanna, Responsabilidad contractual y extracontractual: estudios sobre el incumplimiento de obligaciones y los hechos ilicitos en el derecho y la jurisprudencia civil (trad. española, Lima 2002).

Vodanovic, Antonio, Curso de derecho civil basado en las explicaciones de don Arturo Alessandri y Manuel Somarriva, III: De las Obligaciones (Santiago, 1941).

WIGNY, Pierre, Responsabilité contractuelle et force majeure, en RTDC. (1935). 